\title{
BADEN and HESSE (DARMSTADT)
}




\title{
DARMSTADT
}

\section{FO 30/239: Robert B. D. Morier to Earl Granville, Most Confidential, No 3, Darmstadt, 18 March 187 I}

\author{
[Received 20 March by Messenger Biehl. For: The Queen / Gladstone / Circulate /
} G[ranville]]

Conversation with Prince Alexander of Hesse respecting rumoured treaty between Russia and Prussia in Fune 1870

I took occasion of a visit paid to me the other day by Baron Dalwigk to ask him whether at the time of the Emperor of Russia's visit to the King of Prussia at Ems in the latter days of May and the beginning of June last year, he had heard any thing of the Treaty which it was now currently reported had been concluded between Prussia \& Russia on that occasion. ${ }^{1}$ His Excellency assured me that he had never then or since heard any thing which could lead him to believe that a treaty such as that suggested had on that occasion been concluded, and though he did not doubt that from an early date a clear understanding had been arrived at between the two Governments by which Prussia was assured not only of Russia's neutrality but of her assistance in the event of Austria's joining with France he did not believe that this understanding had been recorded in so formal an instrument as a treaty.

I had occasion the next day to see Prince Alexander of Hesse who, as Your Lordship is aware, is the favorite brother of the Empress of Russia. ${ }^{2} \mathrm{He}$ had been at Ems during the whole period of the Emperor Alexander's visit and he volunteered in the course of conversation to advert to the rumoured treaty and to state it to be his belief that nothing of a political character had been transacted at Ems and his positive conviction that nothing of a formal kind had been concluded. He knew the Emperor Alexander's mode of transacting business too well not to be certain that he would never commit himself to any political step in the absence of any of his political advisers; now not

\footnotetext{
${ }^{1}$ Alexander II stayed at Ems from I5 May to I2 June I870; he was visited by Wilhelm I from I to 4 June.

${ }^{2}$ Maria Alexandrovna.
} 
only was Prince Gortchakoff not at Ems but in the whole of the Emperor's suite there was not a single person who could pretend to the character of an "homme politique".

I observed that what appeared to have given rise to the rumour was the fact of Count Bismarck's sudden appearance at Ems from his retreat at Varzin. ${ }^{3}$ The Federal Chancellor in common estimation was not supposed to be addicted to sacrifice his personal comfort or to undertake long journeys for mere purpose of Court etiquette and without being moved thereto by some political motive. I added that persons not unacquainted with the official atmosphere of Berlin had repeatedly told me that from the moment the result of the plébiscite and the adverse vote of the army were known, ${ }^{4}$ promptly followed as those events were by the nomination of the Duc de Gramont to the post of Foreign Minister, ${ }^{5}$ the Prussian Government had convinced themselves that the long dreaded catastrophe of a collision with France was at hand and could no longer be staved off. Under these circumstances people naturally inferred that the chances of such a conflict and the combinations arising out of it were likely to have been discussed by the August relatives on the occasion of their meeting at Ems. I made this Statement in order to elicit from the Prince whether during the course of his visit any thing had fallen from the Emperor which could have led him to believe that the prospect of a war with France had been discussed. He replied that this was an entirely new view of the matter to him and that he had always believed that the war had come as unexpectedly upon the Prussian Government as it had upon the rest of the world. I was unable to detect from any thing he said that he had gathered anything at Ems leading him to the belief that the peace of Europe hung upon a thread so soon to be snapped asunder.

Prince Alexander mentioned two more facts not without interest.

The one was that on the breaking out of the $\operatorname{war}^{6}$ he had received a letter from his brother in law in which the Emperor said: Our Neutrality depends on Austria's; - si l'autriche marche, nous marchons - without however alluding where he meant to march to mais la direction de la marche, added the Prince, n'était pas difficile à

\footnotetext{
${ }^{3}$ Bismarck - together with Wilhelm I - arrived at Ems from Berlin. He met Alexander II on 2 and 3 June.

${ }^{4}$ Napoleon III's liberal constitutional reforms were overwhelmingly approved in the plebiscite of 8 May I87o, although 40,000 soldiers voted against him.

${ }^{5}$ Gramont was appointed French foreign minister on I5 May i87o.

${ }^{6}$ The Franco-Prussian War began on I9 July 1870 (after France declared war on Germany).
} 
deviner. ${ }^{7}$ It was clear this letter was intended for further transmission to Vienna.

The other was that he had had a letter from his sister at the time of the Gortschakoff Circular ${ }^{8}$ in which the Empress said that it appeared that Count Bismarck had been taken quite as much by surprize by the Russian Circular as the rest of the world had.

In estimating the value to be attached to the above statements it should be noted that Prince Alexander's close relationship to the Russian Court and the innumerable favours he has received from the Emperor \& Empress give him a natural bias in favor of the Emperor, but that on the other hand his political sympathies are supposed to be altogether on the side of Austria where he served for many years and where he won the laurels to which he was unable to add in I866. ${ }^{9}$

Supposing that at the instigation of the Federal Chancellor a confidential exchange of ideas respecting a possible war with France took place between the two Sovereigns it is certain that the attitude of Russia relatively to Austria must have played an important part in such a discussion. In such a case the Emperor would as carefully have avoided in conversing with his brother in law any reference to what had taken place as he afterwards ostentatiously informed him of his programme when it was convenient that the Austrian Court should know of it. I attach therefore no importance to Prince Alexander's ignorance of any "pourparlers" that may have taken place at Ems. On the other hand I think that his evidence establishes conclusively that no formal transaction was concluded.

My own conviction, aimed at by putting together many minute pieces of evidence collected during the course of the war, is that:

I. ${ }^{\text {st }}$ A very clear understanding was arrived at at a very early period between Russia \& Prussia in respect to the attitude which the former would assume in case of a war between the latter and France, and that in all probability on this or perhaps a somewhat later occasion Prussia promised her good offices in regard to the Black Sea Question just as Count Beust did in 1867 and as it is said that General Fleury did on behalf of France last year, but that no position of this understanding ever took the shape of a treaty. ${ }^{10}$

\footnotetext{
${ }^{7}$ 'If Austria marches, we will march' - 'but the direction of the march was not difficult to guess.'

${ }^{8}$ Gorchakov's circular of 3 I October 1870 to the ambassadors at the courts of the signatory Powers of the Treaty of Paris (1856) repudiated the Black Sea clauses of the Treaty of Paris of 1856 , which limited Russian sovereign rights.

${ }^{9}$ In I866, during the Austro-Prussian War, Alexander commanded the 8th federal army corps.

${ }^{10}$ In January I867 Beust proposed a congress on the Balkans and Crete, and suggested revising Russia's position in the Black Sea. The Treaty of Paris of 1856 was discussed
} 
2. ${ }^{\text {ly }}$ that the Gortschakoff circular not only found no part of the understanding but that it took the Prussian Cabinet wholly by surprise at a moment when for some cause or the other there was a momentary coolness between the two Gov ${ }^{\text {ts }}$ and that it was a blow struck quite as much at Prussia, if not more, than at the other cosignatories by Prince Gortschakoff behind the Emperor's back.

\section{FO 30/239: Robert B. D. Morier to Earl Granville, Confidential, No 6 Darmstadt, 8 April 187 I}

[Received ro April by messenger to Berlin. For: The Queen / Gladstone / Circulate / G[ranville]]

\section{Rumour of Dalwigk's resignation}

Reports very generally accredited have been circulated during the last week to the effect that Baron Dalwigk is at last going to resign and make room for a successor, who, it is said, will be either M. Hoffmann [sic], the present Hessian Minister at Berlin, or Baron Rabenau, national liberal member of the German Parliament for Upper Hesse, or Count Görtz.

I have not been able to ascertain what degree of truth is to be attached to these rumours but there is, I believe little doubt, that H.E. [His Excellency] is less firmly seated in the office to which he so much desires to cling than he has ever been before.

I have so often adverted to Baron Dalwigk's abnormal position as the Minister of a State, the first condition of whose existence consists in cultivating good relations with Prussia, that I need hardly do so again.

A man, who won his spurs as the trusted ally of M. de Beust against Prussia in the skirmishes which preceded the catastrophe of I866 and the culminating act in whose official career was the determined hostility of his attitude $\mathrm{ag}^{\mathrm{t}}$ Prussia in that year, ought to have seen thus having lost the game it would have been more dignified as regarded himself and more patriotic as regarded his country, to retire like his colleagues $^{\text {II }}$ in two other States of the Anti Prussian Coalition. The position of a retired minister however is one which I have perceived is little sought after in these small countries and Baron Dalwigk clung to his post. He has always since, I believe, done what Berlin has told

${ }^{11}$ Friedrich Ferdinand von Beust (Saxony) and Ludwig von der Pfordten (Bavaria). 
him to do: but he has always waited to be told, which was naturally annoying to persons desirous that the new federal machinery should appear to be moving smoothly on its' own wheels. On the other hand he made no secret of his hopes that the structure of $1866^{12}$ would be but a provisional edifice and that there was a good time coming in which Prussia would bite the dust.

When the crisis of 1870 came the national party, as I reported to Your Lordship at the time, made a violent attack upon him which failed. ${ }^{13}$ The events which have take [sic] place since, however, have not been favorable to him. He was left unnoticed by the Southern States when they made their arrangement for entering into the new Confederation with Prussia. ${ }^{14}$ He was left equally unnoticed by the Federal Chancellor (whose agent M. Delbrück went to Münich Stuttgardt \& Carlsruhe but never called at Darmstadt) and had at the last moment, when the Representatives of Bavaria, Würtemberg and Baden had already been some time at Versailles, to telegraph and ask permission to repair to Head Quarters uninvited. ${ }^{15}$

The crowning act by which the Imperial Chancellor shewed the value which he set upon the cooperation of Hesse so long as she was in the hand of her present Minister was ignoring her existence in the negotiations for peace. The three Southern States were summoned to send Plenipotentiaries to assist both at the negotiations carried on at Versailles and those now going on at Brussels. ${ }^{16}$ Hesse though as regards her Southern Provinces and the international Status of her Sovereign situated in exactly the same position as the other States of the South has been passed over under silence.

This marked expression of displeasure on the part of the Imperial Gov $^{t}$ has naturally given strength to the feeling existing $\mathrm{ag}^{\mathrm{t}}$ Baron Dalwigk in the ranks of the National Party, a feeling which found vent

${ }^{12}$ North German Confederation; of which the Upper Hesse province was part.

${ }^{13}$ According to Morier's dispatch No I4 to Granville of 22 July I87o the National Liberals, who accused Dalwigk of pro-French leanings and an alliance with the ultramontanes, attempted 'to induce Prince Louis [later Ludwig IV] to assist them in their attacks against the Hessian government.'

${ }^{14}$ Morier is probably referring to the conferences of Bavaria, Württemberg, and the North German Confederation at Munich, 22 to 26 September i87o.

${ }^{15}$ The conferences at Versailles in October and November I87o led to the so-called November Treaties of $\mathrm{I}_{5}, 23$, and 25 November 1870 , by which the South German States (Baden, Hesse, Bavaria, and Württemberg) joined the North German Confederation. In a telegram of 20 October I870, Dalwigk instructed the Hessian envoy to Berlin, Hofmann, to inquire whether his attendance would be convenient to Bismarck.

${ }^{16}$ Negotiations for the preliminary peace took place at Versailles from 2I February to 26 February $187 \mathrm{I}$ when the Treaty of Versailles was signed. Further negations for a final treaty commenced at Brussels on 28 March. 
in the elections for the German Parliament ${ }^{17}$ at which all the Gov $^{t}$ Candidates were defeated by immense majorities.

Nevertheless Baron Dalwigk's remaining or not remaining in office depending, as it does, wholly on the Grand Duke's pleasure and His Royal Highness' dislike of change and of the trouble which any new ministerial combination might cause him being the main spring of his political action or rather inaction, there would still be chance for Baron Dalwigk were it not that I am told that the Grand Duke has been personally annoyed by his own name having been mixed up of late with the attacks made upon his Ministers.

\section{FO 30/239: Edmund W. Cope to Earl Granville, No ro, Darmstadt, 9 October I87I}

[Received i6 October by messenger. For: The Queen / Gladstone / Circulate / Rome]

Resolutions passed at $5^{\text {th }}$ German Protestant Congress

The fifth German Protestant Congress assembled at Darmstadt on the $4^{\text {th }}$ Instant, and was largely attended by Representatives of Protestant Associations from different parts of Germany, and also by some delegates sent from other Countries, Professor Bluntschli, who was chosen one of the Presidents, in his speech attacked the order of Jesuits, and especially their right of association, held by many Protestants to be perfectly legitimate, and considered the order should be prohibited in Germany. ${ }^{18}$

The Congress passed the two resolutions, which I have the honor to transmit herewith in Copy and translation. ${ }^{19}$ The following day another resolution was passed by the Congress in favor of the Establishment of a German National Church with entire freedom for religious convictions and the investigations of science; this being directed against the so-called pietist party. ${ }^{20}$

A general meeting of Hessian Protestants on the same day not only endorsed these resolutions, but also proposed to memorialize

\footnotetext{
${ }^{17}$ Elections for the Reichstag took place on 3 March I87I.

${ }^{18}$ The congress was held by the Deutscher Protestantenverein (established 1863 ) from 4 to 5 October I87I.

${ }^{19}$ Enclosures: undated newspaper clipping (Darmstädter Zeitung) and translation of

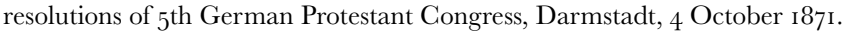

${ }^{20}$ The 3 rd resolution of the assembly of Hessian Protestants of 5 October 1871 was directed against the so-called Protestant papists; Pietism, which - despite its traditional precept of tolerance - also opposed liberal and rationalist tendencies within the church, is not mentioned in the resolution.
} 
The Grand Duke, the Reichstag and the Chancellor of the Empire on the subject, and called on all Protestants in Hesse, and those of their Roman Catholic country men who had not as yet yielded to ultramontanism, to join in combating it, and the advances of the Jesuits. ${ }^{21}$ This meeting also passed a resolution relative to the Constitution of the Protestant Church in the Grand Duchy and the law of presentation, ${ }^{22}$ in favor of the liberty of religious convictions.

These resolutions of the Protestant Congress show what a degree of irritation the dogma of the Papal Infallibility ${ }^{23}$ has caused and continues to excite in Germany, for it is hard to imagine the same individuals advocating freedom of religious conviction on the one hand, and clamoring for the State to interfere with the right of association on the other. Probably the Protestant party fear that the union of Germany being now accomplished, the fact of so much of the South being Catholic, may be an incentive to the Jesuits to organize with the Catholics of Westphalia, the Rhine, Posen, and other parts of the North, a party for putting a pressure on the Reichstag for carrying out ultramontane ideas, and with an excess of prudence have begun to cry before they are really hurt, and hence the resolution for the prohibition of the Order of Jesuits in Germany, which order has however, I believe, but twelve houses at the present moment.

\section{FO 3o/240: Evan Montagu Baillie to Earl Granville, No I6, Darmstadt, 6 June 1872}

[Received ro June by messenger. For: The Queen / Gladstone / Home Office; G[ranville]]

\section{Social Democratic agitation in Hesse and Baden}

I had the honor in a previous Despatch to express to Your Lordship my apprehension that the Agitators of the Social Democratic Party would find in the Grand Duchy of Hesse a soil favorable for sowing seeds of their pernicious principles, and that these doctrines would be likely to take root and flourish here and I pointed out to Your Lordship the striking contrast that was observable in respect to the

\footnotetext{
${ }^{21}$ Cope is referring to the Ist resolution of the assembly of Hessian Protestants of 5 October I87I.

${ }^{22}$ The 2 nd resolution of the assembly of Hessian Protestants of 5 October i87i referred to the draft constitution of the evangelical church contemporaneously under discussion and demanded free elections of parish councils. Furthermore, it urged the abolition of the ancient right of patrons to propose a priest on the occasion of a vacancy, which applied to one-third of evangelical parishes in Hesse.

${ }^{23} \mathrm{See}$ n. I I in Munich section.
} 
moral condition of the working classes, between the Grand Duchy of Baden which has for many years enjoyed the blessing of a liberal and patriotic Government and this country which has been one of the principal centres of a reactionary and anti national policy.

I regret to say that the Experience of the last few months has only tended to confirm my apprehension.

As far as I am aware the socialist intrigues in Baden have totally failed. I do not assert that there have been no demands for increase of wages there but there have been no strikes worthy of the name, and any differences that have arisen between Master and workmen have been speedily adjusted without any injurious influence having been exercised upon the progress of business and Trade.

In this country on the other hand the case has been very different. The Socialist Agitators have long been hard at work here especially in the town of Mayence. Trade Unions have been founded, funds raised by Contributions of the members to meet the loss of wages and travelling Expenses, and strikes organized on the System adopted in Leipzig \& Berlin[.]

These experiments have indeed inflicted on the work people [sic] than on the Masters, but they had the effect for a time of bringing trade in several branches to a complete stand still.

Most of the differences have now at last been compromised by a Io per cent increase of wages, and a reduction of the number of the hours of labor[.]

It is not easy to say how far this increase of wages is a fair one, but the general rate of wages has so much risen that many trades people can barely afford to carry on their business. The Shoemaking Trade in Mayence appears to have suffered the most. The workmen demanded 20 p. cent increase of wages and after months of negotiation the Masters finally decided in refusing all compromise whereupon about two hundred workmen took their departure and the rest yielded.

The Masters have now combined among themselves in self defence, and also with the object of sheltering the honest workmen against the terrorism of the Unions.

They have established advertising offices for labor, and have agreed among themselves to engage no workmen who they may consider to have been unjustifiably implicated in any strike.

They have further taken steps for establishing an industrial Tribunal of Arbitration and an Office for arranging differences.

A large meeting has just taken place at Cassel ${ }^{24}$ of the Representatives of the Tobacco and Cigar Manufacturing Firms from

\footnotetext{
${ }^{24}$ The meeting was held on 27 May and saw the formation of the Verein der deutschen Zigarrenund Tabakfabrikanten.
} 
all parts of Germany for a similar object, and apart from those immediately interested there are abundant signs that this important social question is engaging more and more, the attention of all classes of the people.

\section{FO 30/240: Evan Montagu Baillie to Earl Granville, No I8, Carlsruhe, 26 June 1872}

[Received I July by messenger. For: The Queen / Gladstone / Circulate; G[ranville]]

Conservative press reflects general public opinion on relationship between Germany and Rome; socialist agitation; gloomy apprehensions for future of Germany

I have the honor to forward in original and translation two articles from the Sud Deutsche Reichs Post, the organ of the National Conservative Party as shewing the direction in which Public Opinion is now moving in regard to the Question between Germany and Rome. ${ }^{25}$

The Conservatives have been hitherto so averse to measures of a liberal tendency, that they have generally opposed the Policy adopted by Government in their struggle with Baden Jesuits and the Curia of Freiburg, a Policy precisely similar to that which is now to be applied throughout Germany. ${ }^{26}$ The Conservative Party have always been inclined to regard the Baden Jesuits with a certain amount of charity and indulgence as forming a wholesome counterpoise to the Liberalism of the Government, and as the upholders of positive religion against the supposed infidel tendencies of the day.

Their tone has now completely changed, in a great degree owing no doubt to the effect produced by the Debates in the Reichstag at Berlin. ${ }^{27}$

The Vatican Council ${ }^{28}$ and the French War are now viewed as the result and outbreak of a vast conspiracy directed from Rome against the liberties of Europe, one great object having been to crush Prussia and render the Unity of Germany impossible. In short the language

\footnotetext{
${ }^{25}$ Enclosures: undated clippings from Süddeutsche Reichspost and translations: 'TagesUebersicht' ('Daily Summary') and 'Der Kampf gegen Rom' ('The Battle against Rome').

${ }^{26}$ Baillie is referring to the laws of 2 April 1872 , which banned members of orders from public teaching and forbade proselytizing activities in Baden, as well as to the conflict on compulsory state exams for theology students of both denominations. These Kulturexamen were introduced in 1867 and subsequently disregarded, indeed prohibited, by the Archbishop of Freiburg.

${ }^{27}$ On I9 June the Reichstag passed the anti-Jesuit bill which banned the Jesuit Order in the German Empire (law of 4 July I872).

${ }^{28} \mathrm{See} \mathrm{n}$. II in Munich section.
} 
of the Conservative Press is quite as strong as anything to be found in the liberal Journals.

Another question which is now attracting the attention of the Public, is the encouragement which the Priests are apparently giving to the socialist agitation.

Independently of the numerous strikes which have taken place in various places, there is a spirit of restlessness and discontent observable among the working classes everywhere, and the best Masters are Complaining of the difficulties they meet with in dealing with their men.

Many people are disposed to take a very gloomy view of the social condition of Germany[.]

Such persons fear that the rise of wages and consequent rise of the price of all the necessaries of life will eventually affect very seriously large numbers among the middle classes, especially public servants and officials with fixed incomes, who they fear will soon be utterly unable to meet the increased expense of living and be plunged into the greatest distress[.]

There is undoubtedly much room for gloomy apprehension, for Germany is now divided into two hostile Camps and embarked in a struggle which admits of no compromise and from which it is impossible for either side to retire.

\section{FO 30/240: Edmund W. Gope to Earl Granville, No 4, Darmstadt, 27 July 1872}

[Received 5 August by messenger. For: The Queen / Gladstone / Circulate; Qy: Rome / Berlin; G[ranville]]

\section{Formation of Association of German Catholics in Hesse; remarks on religious conflict}

A Society calling itself the "Verein der Deutsche [sic] Katholiken", "Union of German Catholics", lately formed at Mayence has issued an Address ${ }^{29}$ to the Catholics of Germany on the subject of the so: called persecution of the Church, by which is meant, I conclude, the Law against the Jesuits and the recent attacks on the Ultramontanes in a part of the German press.

The President of the Society is Baron Felix v. Loe of Terporten and amongst a list of names of members of different Catholic Families of

\footnotetext{
${ }^{29}$ Founding Manifesto of the Association of German Catholics, Mainz, 8 July I872. The Verein der deutschen Katholiken was founded in consequence of the Anti-Jesuit Law of 4 July (see n. 27 in this section) and the papal declaration of 24 June, which authorized German Catholics' resistance to state measures.
} 
this and other parts of Germany who are on the Committee the two chief names of those belonging to Hesse are Prince Ysenburg=Birstein and Baron Franz von Wambolt.

The address issued by the Society closes as follows;

"For GOD and Fatherland shall be our motto in the battle for which we prepare in this earnest moment. But only through unity can we hope to conquer, therefore must all the Catholic men of Germany agree as to the principles which are to direct their public conduct. They must unite in common action in order to exercise a proper influence on political life. Only by a steady and comprehensive organization can we be in the position to support our Press against the superior force of the enemy, in political elections to give effect to our votes, and to obtain for our interests a hearing from the Governments. In order to bring about such Unity among all German Catholics, a Society has lately been founded in Mayence the Statutes of which the above mentioned Committee ${ }^{30}$ publish. All Catholic men in Germany who have at heart the liberty of the Church as well as the well being of the Fatherland are invited to enter it. The most holy endowments are in danger. Let us rouse ourselves then as true sons of the Church and the Fatherland. Let us fight perseveringly and fearlessly for right and truth for Right must remain Right and the final victory must be on the side of truth" [.]

It is much to be regretted that the Ultramontane Press on the one hand and a certain part of the what can better be called the would-be Liberal, than the Liberal, Press on the other continue to do all they can to foment religious differences in Germany, and it is a pity that instead of supporting the Press of one side as above suggested in the address, sensible men of both sides do not do more to write down those Papers which continue senseless and useless attacks whether directed against one side or the other. At the present moment the people most to be pitied in Germany are those Catholics, who having no wish to mix religion with politics, simply desire to worship GOD as their Great Grandfathers did before them, these are pestered to give their names to societies and their money to subscriptions for the Church in danger, while the extreme party of the other way of thinking are inclined to look upon them as so many Agents of the Jesuits.

As yet only two moves have been made, since the passing in Berlin of the Law relative to the Jesuits of the $4^{\text {th }}$ of July, by the Government here which have attracted the attention of the above: mentioned combatants, one was that a circular was sent on the occasion of the publication of the Law relative to the Jesuits in the Grand Duchy, to the different prefectures asking if there were Jesuits residing in

\footnotetext{
${ }^{3^{\circ}}$ The executive committee of the association.
} 
the Department and if so how many. ${ }^{31}$ The second was that the Government ceased to use the "Mainzer Journal", the organ of Bishop Ketteler, as the Paper for the insertion of the different Government notices for the Province of Rhein Hesse as hitherto, and gave them to the "Mainzer Tageblatt" another paper published in Mayence..$^{32}$ Simple as these two things are they caused a sort of crow of defiance from the Ultramontanes and a kind of cry for more from the other extreme party, it is not expected that either the pugnacity of the one party or the rapacity of the other will be gratified. The Ministry at present in power will not wish for anything better than to let alone and be left alone and if they are stirred to anything it must be through some unusual pressure from without, they are as certain to show no spirited opposition to such pressure should it come, as they are sure to oppose it with all the vis inertiae possible.

I do not anticipate that much will be done from Berlin unless the Hessian Ultramontanes from sniffing the fray too often, and being pecked at too much by the other extreme party should get more troublesome, anything like a regular persecution of individual Jesuits would only make them martyrs in the eyes of many who consider at present that it is quite possible for Germany to get on without them, and whether it was really advisable or not to promulgate the Law, which is not for me to discuss, it would utterly defeat its purpose if the individual members were through persecution to work on in secret under false colors, for it is not probable that those who wish to do so will be able to localize the whole Society of Jesus where they wish and draw a cordon round it like a herd infected with Rinderpest[.]

\section{FO 3o/241: Evan Montagu Baillie to Earl Granville, No 9, Darmstadt, 28 April 1873}

[Received I May by private hand. For: The Queen / Gladstone / Circulate; Qy: Berlin; G[ranville]]

Beer riots in Frankfurt and other towns; not the result of dissatisfaction with Prussian rule; general observations on public feeling towards Prussia

A few weeks ago the towns of Constance and Mannheim in the Grand Duchy of Baden were the scene of riots of rather an alarming character,

\footnotetext{
${ }^{31}$ The Anti-Jesuit Law was published on Io July I872. The circular in question was issued on request of the imperial government.

${ }^{32}$ Notification of judicial announcements in the province of Rheinhessen; published in the Großherzoglich Hessisches Regierungsblatt, I9 July 1872.
} 
of which the ostensible cause was a rise in the price of a glass of beer from four to four and a half Kreutzer. ${ }^{33}$

As these demonstrations of popular discontent were secretly planned in the workmen's clubs, aided no doubt by Agents of the "Internationale" ${ }_{34}$ who are everywhere active in sowing the seeds of mischief, the authorities were taken by surprise, and before the assistance of the troops could be obtained, several breweries were demolished with a very considerable loss of property.

The mob, however, was eventually dispersed without bloodshed, and, as far as I am aware, without any loss of life.

The town of Frankfurt has just been visited by a similar calamity, but unhappily in the struggle to restore order, sixteen persons appear to have been killed, and upwards of forty wounded. ${ }^{35}$

The causes of this last riot were exactly the same as they were in Baden, and perfectly clear and unmistakable. Comparatively few, however, of the Frankfurt workmen were engaged in it; the mass came from Offenbach, Hanau, and other towns of the neighbourhood, and were simply intent upon plunder. They are discontented at the rise in the price of provisions, following, as it necessarily must, from a general rise of wages, and the addition of half a Kreutzer to the price of a glass of beer, formed a convenient pretext for a demonstration.

I have nevertheless observed a letter from a British correspondent at Frankfurt in the "Times", ${ }^{36}$ in which the writer attributes a popular character to the riot, as he says that it has its origin in the universal dissatisfaction felt with the Prussian system of Government. ${ }^{37}$

This statement is so absurd that it scarcely deserves notice: and to any one who knows any thing about this part of the country, it can only serve to show that the writer is a sympathiser with one or other of those extreme parties who never lose an opportunity of endeavouring to excite the people against the Prussian Government.

The bitterness felt by the Frankfort people against Prussia after I866, has been much softened, and to a great degree obliterated by the war, uniting, as it did, all parties against a common enemy.

Moreover Frankfurt, instead of exhibiting any of the symptoms of a once flourishing town falling into decay and insignificance, as was

\footnotetext{
${ }^{33}$ The events (Bierstreik) took place at Constance on I2 April and at Mannheim on I6 April I872.

${ }^{34}$ The Mannheim beer boycott was initiated by the local branch of the General German Workers' Association (ADAV); any outside influences or the involvement of the International (see n. Io in Dresden section) were unlikely.

${ }^{35}$ The Frankfurt Bierkrawall of 2 I April I873 saw 20 fatalities.

${ }^{36}$ The Times, 25 April I873, p. 5; the name of the correspondent is not traceable.

${ }^{37}$ In I866, during the Austro-Prussian War, the Free City of Frankfurt was annexed by Prussia; in 1868 it was incorporated into the newly formed Hesse-Nassau province.
} 
predicted would be the case, appears on the contrary, to be reanimated with fresh vigour, and has advanced, and is still progressing on the path of wealth and general prosperity.

The people of Frankfort have consequently no ground to be dissatisfied with the Prussian Government.

They have had time to reflect that there is a certain connexion between Commercial prosperity and the character of Government, and they cannot fail to perceive at the same time that the Prussian Government, whatever its faults may be, is fully able to cope with those extreme parties which aim on the one side, to sap the foundations of all liberal progress, and on the other, to destroy the foundations of society itself; and who are now acting to a great degree in concert as the avowed enemies of the Empire.

The mask is now thrown off, and it is clear to all what hostility to the Empire really means.

The people of Hesse who were at one time little, if at all less disaffected to Prussia than the Frankfurters, returned to the Hessian Parliament at the late Elections ${ }^{38}$ members, with the exception of a very small and insignificant minority, who are unanimous in supporting the present liberal and national Government.

Such a fact as this speaks for itself, and shows what a remarkable change has passed over the minds of the people in the last few years.

The writer of the letter to which I have alluded also says that the troops not only did what they could to provoke the people, but that they fired upon an inoffensive and "laughing" crowd.

The troops on the contrary behaved with great moderation. In attempting to arrest the ringleaders, they were pelted with stones and bricks. In the first instance they replied with a volley of blank cartridges, and it was not until after resistance had been repeated, that they sent a volley of bullets among the mob.

It is, however, I fear, quite true that the Frankfurt authorities, though they expected a riot, were culpably negligent in not taking care that an imposing mass of troops were at hand, ready to act at the first appearance of a disturbance. If this had been done, in all probability the mob would have quickly dispersed, as was the case at Mannheim, and firing would have been unnecessary.

It is not at all impossible that similar disturbances will be attempted in general towns in Hesse, but I understand that the necessary precautions are taken. The military will be at hand and the authorities well prepared.

\footnotetext{
${ }^{38}$ Elections to the second chamber of the Hessian Landstände were held in December I872; National Liberal candidates won 40 of 50 seats.
} 


\section{FO 30/241: Hubert E. H. Jerningham to Earl Granville, No 2, Darmstadt, 8 August 1873}

[Received II August. For: The Queen / Gladstone / Circulate / Rome / Berlin / Paris; G[ranville]]

Conversation with Bishop Ketteler on Bismarck's 'cynical' attitude towards legislation regarding Catholics

I had the occasion a short time back at Mayence of being presented to Monseigneur Ketteler, Bishop of that city, and, as Your Lordship is aware, the Catholic Champion of Southern Germany.

$\mathrm{He}$ is a Prussian nobleman by birth, and has always enjoyed much consideration at Berlin as a patriot and a man of great ability.

The conversation with which he favoured me appears to me so interesting in the present state of the conflict between Prince Bismarck and the Church of Rome in Germany, that I venture to acquaint Your Lordship with its substance, though I am aware it can have but an historical value.

The Bishop at once began on the subject which is uppermost in his mind, i e. the absence of religious faith which he deplores in his native land and to which he attributes all the misfortunes that beset his party.

"The progress of rationalism and of positivism, he said, is such, that it requires on the part of those whose duty it is to combat its encroachments, a degree of faith almost beyond what they can reasonably expect from the divine grace."

"Happy England", he exclaimed, ["]there you still have the life of Christianity in a religious conviction. Would that I could say the same of Germany."

"To believe, that is the great point: the "hauptsache", but the torrent of rationalism is daily weakening the religious faith that remains, and I except no religious denomination."

Monseigneur Ketteler then got very animated on the subject of Prince Bismarck, and what he called that statesman's "wicked cynicism", and proceeded to illustrate his meaning by the following account of a conversation he had had with the Prince. ${ }^{39}$

It would seem, as Monsigneur Ketteler explained to me, that the laws in Prussia defining the relations of the Church and the State as they existed before I870 were of an essentially liberal character. The Bishop I believe, meant liberal in the sense that these laws which were passed in $1850^{4^{\circ}}$ by a party anxious to proclaim a free church in the

\footnotetext{
${ }^{39}$ Ketteler conversed with Bismarck on 16 November i87I. At the time Ketteler was a member of the Reichstag.

${ }^{4^{\circ}}$ The Prussian constitution of $3^{\mathrm{I}}$ January $185^{\circ}$ guaranteed freedom of religious belief (Article I2) and restricted state interference in ecclesiastical affairs.
} 
free State, were favorable to the Catholics of Prussia. In the new laws, however, which are being framed, and to be enforced throughout the newly constituted Empire of Germany, it is proposed to introduce regulations copied, so I understood, upon those already in existence in Baden and in Bavaria, but principally in the former. ${ }^{4}$

Though Bavaria is essentially a Catholic Country, it would appear that the relations of the Church and the State since the abrogation of the Bavarian Concordat ${ }^{42}$ are such that the Catholics are not so favoured as they were in Prussia under Protestant rulers.

Monsignor Ketteler fought Prince Bismarck, therefore, on the ground that the existing laws should be retained in the new German code, advocating as his principal reason that the union of the Church and of the State are necessary to the peace and unity of the German Fatherland.

Prince Bismarck's reply was characteristic.

"Believe me, Monseigneur, he said, no other but political combinations actuate my conduct. I am the servant of my country and a workman for its good and its prosperity."

"I will be perfectly frank with you."

"If in I850 we framed laws that were favorable to the Catholics, the reason is that we wanted their support at that time, and we naturally had to conciliate them."

"Matters have changed now and it is indispensable for me to have a liberal majority to depend on."

"This I cannot obtain without conciliating both Baden and Bavaria. I must therefore entertain the proposed modifications and promote their success."

"Your Grace is at liberty to combat me by all the means in your power: indeed I hope you may succeed, for, believe me, I have not expressed to you that which I feel: I have only told you my political convictions. I have given you the arguments of reason and of policy, not those of the heart, for I can assure you I would not for worlds endanger the salvation of my soul."

Bishop Ketteler was very much excited all the while he told me of this interview, and his tone was almost imploring in his desire to know whether a greater show of cynicism had ever before been exhibited.

\footnotetext{
${ }^{41} \mathrm{~J}$ Jerningham is referring to the five Baden church laws of 9 October I860 which regulated the relationship between the state and the Catholic Church as well as further decrees and laws, including the regulation of church property (I86I), government supervision of schools (1862, I864, and I868), state exams for students of theology (I867), civil marriage (I869), and church foundations (I870).

${ }^{42}$ In contrast to the short-lived Baden concordat of 1859 , which was revoked the following year, the Bavarian concordat of 1817 remained in existence until 1918 .
} 
I ventured to improve the opportunity thus afforded me of learning Monseigneur Ketteler's views generally, by asking him what importance he attached to the Old Catholic movement. ${ }^{43}$

He replied that he attached no importance to it whatever and added that if it had not enjoyed political support in Baden and elsewhere in Germany but principally in Prussia, it would have died out altogether, for, added the Bishop continuing his old line of argument, with few exceptions, those who have joined the movement are men who had long lived in that unfortunate state of want of faith which he so much deplored, and had, therefore, long been out of the pale of the Catholic Church.

I may, however, point out to Your Lordship a passage in a pamphlet ${ }^{44}$ published a short time back by Monseigneur Ketteler which shows at least that in his own mind, he attaches more importance to the Old Catholic movement than he apparently was willing to acknowledge in conversation with me, for he complains of its being one of the instruments in the hands of the liberal party intended to weaken the Catholic cause in Germany.

"The object of the national liberal party is forcibly to tear the links which unite the Catholic Church and the people, using as a means to this end both Protestantism, the religion of the State, and the Old Catholics".

\section{FO 30/24I: Hubert E. H. Jerningham to Earl Granville, No 7, Darmstadt, 12 September 1873}

[Received I5 September. For: The Queen / Gladstone / Circulate / Paris / Berlin / Rome; G[ranville]]

Old Catholic movement; great impression made by Bishop Reinkens's pastoral; support from governments in Hesse and Baden; Prussia irritated

The pastoral of Bishop Reinkens ${ }^{45}$ on the occasion of his election as Head of the "Old Catholics" of Germany, or Head of the "Royal Prussian religion" as Bishop Ketteler has lately denominated that body of secessionists from the Roman Church continues to produce a good deal of impression in this part of Germany, and appears to be assuming the character of a political Manifesto.

\footnotetext{
${ }^{43}$ For the Old Catholic movement, see n. 36 in Berlin section.

${ }^{44}$ Die preussischen Gesetzentwürfe über die Stellung der Kirche zum Staat, Mainz 1873.

${ }^{45}$ First Pastoral Letter of I I August I873. For the Old Catholic movement, see n. 36 in Berlin section.
} 
$\mathrm{M}^{\mathrm{r}}$ Hofmann, the Minister for Foreign Affairs told me that in consequence of this pastoral, it will soon become a question with his Government whether they should not afford political support to the "Old Catholics" by recognizing them as an independent religious body and providing them with the means of practising their religion.

Baron de Freydorf with whom I lately had some conversation at Carlsruhe, assures me that the number of "Old Catholics" is greatly on the increase in the Grand Duchy of Baden, and that while his Government has already been obliged to interfere at Freibourg, ${ }^{46}$ he foresees the time, which is not distant, when they will have to support them at Carlsruhe likewise.

M. de Freydorf added that he looked upon Bishop Reinkens' pastoral as the rallying flag (le signe de ralliement) for all AntiInfallibilists.

On the other hand it is not possible to be blind to the fact that in both the Grand Duchies of Hesse and of Baden, but especially in the latter, the Government encourage the old Catholics rather than they allow them to progress on their merits only.

At any other time than the present, such encouragement might pass unnoticed, but when the hostility of the State against the Catholic Church is so marked as it is now in Prussia, the doings of the Ministers in subordinate States are naturally attributed to superior injunctions, and create a corresponding feeling of irritation among the people, who begin to think that the sacrifice of their religious convictions is little by little to be held up as the proof of their patriotism.

This irritation is growing daily, and is carefully fostered by the clergy, who, owing to the measures adopted in Prussia against their body, ${ }^{47}$ find a pretext for declaring themselves to be the objects of an unfair persecution, and for claiming an increased amount of sympathy on the part of their co-religionists.

It thus becomes a question how far the undisguised encouragement by the State of a particular religious sect, with the view of combating another recognized and powerful religious denomination, is likely to produce in this portion of Germany at least, that great and noble result which is so ardently hoped for, viz the merging of all private feelings into one great unity of aspirations for the peace and prosperity of the common German Fatherland.

\footnotetext{
${ }^{46}$ Ministerial decree of 24 March 1873 , which allowed Old Catholics joint use of the University Church at Freiburg.

${ }^{47}$ Jerningham is referring to the Prussian May Laws of 1873 (see n. II2 in Berlin section).
} 


\section{FO 30/ 242: Francis Glare Ford to Earl Granville, No I2, Darmstadt, 7 February 1874}

[Received 9 February by messenger to Cologne. For: The Queen / Gladstone / Circulate; G[ranville]]

Central committee of Old Catholics call upon Germans to declare whether they are on the side of the Pope or otherwise

I have the honour to transmit herewith to Your Lordship a copy and translation of an appeal issued last month by the Central Committee of the old Catholics at Cologne..$^{3}$

The Document is of great length but well repays perusal as embodying the strongest reasons adduced by the Old Catholics in favour of their movement and the justice of their Cause.

The Central Committee considers itself justified in regarding the majority of the population of Germany as non believers in the Dogma of the Infallibility, ${ }^{49}$ and as belonging, on that account by virtue of conscientious conviction, if not by virtue of any public act or deed on their part, to the old Catholic Ranks.

The necessity of such persons coming forward, in a public manner, and registering their names in old Catholic Communities is powerfully urged.

"We now possess, says the Central Committee, an officially recognised Bishop ${ }^{50}$ and a Church organisation: in order then to break the insidious power of Ultramontanism, which undermines the consciences of the people and saps the power of the State, a public declaration of individual views must be made.

Let those who are for Rome and Infallibility stand on one side; let their opponents range themselves on the other, at any rate let us define our position."

It must be remarked, however, that the greatest obstacle the Central Committee will encounter to the success of their appeal lies in the disinclination of most Germans to identify themselves personally with the present religious strife - a disinclination proceeding either from feelings of indifference to religious matters, or from considerations of a purely mundane character, such as fear of creating family disorders \&c.

\footnotetext{
${ }^{48}$ Enclosures: original (Kölnische Zeitung, 28 January 1874) and translation of 'Address of the Central Committee of the Old Catholics for North Germany to the Catholics of Germany'. For the Altkatholiken, see n. 36 in Berlin section.

${ }^{49}$ For the dogma of papal infallibility, see n. I I in Munich section.

${ }^{50}$ Joseph Hubert Reinkens.
} 
It would be difficult to speculate at so early a stage in the creation of the old Catholic movement as to the germs of vitality it may possess.

Opinions differ vastly on the subject; and whilst many predict a purely ephemeral existence to the movement, others assert with confidence that it is daily gaining ground and enrolling fresh proselytes.

Of one fact no doubt can exist: namely that the German Governments are taking the matter vigourously $[\mathrm{sic}]$ in hand and that the privileges[,] countenance and support shown to the old Catholics, particularly in such states as the Grand Duchy of Baden, are likely to foster and develop, if any thing will, the present schism in the Church of Rome.

\section{FO 30/242: Hubert E. H. Jerningham to Earl of Derby, No 6, Darmstadt, I9 June 1874}

[Received 22 June by messenger to Cologne. For: The Queen / Disraeli / Circulate; D [erby]]

Catholic Union congress in Mainz; ultramontane spirit of resistance awakening under pressure of state persecution

The $2^{\text {nd }}$ general Assembly of the "Catholic Union" of Germany ${ }^{51}$ was opened on the $15^{\text {th }}$ Instant in the evening at Mayence, and was attended by Representatives from every province in North and South Germany, the place of meeting $5^{5^{2}}$ proving too small for the accommodation of the members of the Union who had responded to the call.

Judging by the reports hitherto published of the proceedings at the meetings already held, it is a painful sign of the consequences of the religious conflict now going on in Germany that the prevailing spirit of this Congress has proved to be one rather of fanatical Ultramontanism than of wholesome common sense, and that the general tone of the speeches delivered has been that of injured and isolated subjects in an Empire which in common with fellow countrymen of different religious persuasion, they have helped to constitute.

Respectable though this voice of distress may sound, and justifiable though many complaints undoubtedly may seem, it cannot but be deplored that such sentiments should be proclaimed as those recorded in this day's "Allgemeine Zeitung" in a paragraph summing up these

\footnotetext{
${ }^{5}$ For the Verein der deutschen Katholiken, see n. 29 in this section.

${ }^{52}$ Hotel Frankfurter Hof.
} 
debates and which, though perhaps a little strongly put, is not far from the truth when compared with the accounts given of the same by Ultramontane organs such as the "Germania" ${ }_{53}$ and the "Mainzer Journal".

The first principles laid down declare: "modern civilisation to be incompatible (unverträglich) with the Church - that the result of the present strife in Germany is the dissolution of all social and political order - and that salvation is only to be expected from a return of the Pope to his former political independence and traditional rights. $^{5+}$

"Condemning then the laws passed of late years in the German Parliament; the enforced Government supervision of public instruction: the foreign policy of the Empire, especially in regard to its relations with the Holy See, and the bad representation of the nation's interests in the Reichstag by the National party, the Congress agreed that expressions of respect and admiration should be conveyed to the imprisoned Bishops ${ }^{55}$ and clergy for the courage displayed by them in the defence of their sacerdotal and ecclesiastical rights, and that a similar address should be sent to the clergy of Switzerland."

It was finally resolved that the members of the Union should strive by every means in their power to "promote the true interests of individuals, of the Church and of the German people", and "should call upon all Catholics to join the Association."

Your Lordship will notice how painfully keen must the feeling of oppression have become throughout Germany to call for the public expression of sentiments and resolutions which are too narrow minded in their conception, not to be the result of a sense of persecution rather than the vigorous protest of free citizens and subjects.

Indeed it is difficult to denie that the wakening of such a spirit, especially if it seeks an ally as at the time of the last elections ${ }^{56}$ for the German Imperial Parliament, with the discontented radical element in the land, may not point to a troublesome future[.]

\footnotetext{
${ }^{53}$ Germania - Zeitung für das Deutsche Volk.

${ }^{54}$ This refers to the end of the papacy's temporal rule in central Italy after the capture of Rome by Italian troops in September I87o.

${ }^{55}$ See n. 139 in Berlin section.

${ }^{56}$ Elections for the Reichstag were held on io January I874.
} 


\section{FO 30/ 242: Francis Clare Ford to Earl of Derby, No 3o, Darmstadt, 27 August 1874}

[Received 3I August by messenger to Cologne. For: The Queen / Disraeli / Circulate in turn; D[erby]]

Considerable astonishment, which has spread throughout Germany, has been excited in the Grand Duchy of Hesse by the proclamation issued on the $19^{\text {th }}$ instant by Bishop Ketteler at Mayence, prohibiting participation by Roman Catholics in the Fête to be held in German towns of his diocese on the $2^{\text {nd }}$ of September.

That day appears to have been definitively fixed upon as the one in which the military successes of Germany over France will in future be commemorated..$^{57}$

Bishop Ketteler, by attaching a party spirit to the general feeling of Patriotism that has dictated the observance of such a day of rejoicing, has committed a grave error; but by attempting to thwart, on religious grounds, the cooperation of the Roman Catholics in it, he has increased to a high degree the ill feeling already entertained by the majority of Germans to the Ultramontane party.

A perusal of the Bishop's proclamation, of which I have the honour to transmit herewith a copy and translation, will convince Your Lordship of the want of temper and discretion that have prompted its publication. I understand the Catholic Schools in Darmstadt will join the festivities in spite of the Episcopal interdict. ${ }^{58}$

\section{FO 30/242: Francis Glare Ford to Earl of Derby, No 32, Darmstadt, 2 September 1874}

[Received 7 September by messenger to Cologne. For: Disraeli / Chancellor of the Exchequer; D[erby]]

Introduction of new Mark currency in southern German states; concerns in Hesse over price rises

On the $\mathrm{I}^{\text {st }}$ of January i 875 , the Baden Government have notified their intention of introducing the Marck [sic] currency adopted in Prussia,

${ }^{57}$ The 2 September was known as Sedan Day. It was - semi-officially - intended to commemorate the German victory in the Battle of Sedan during the Franco-Prussian War and the capitulation of the French emperor, Napoleon III.

${ }^{58}$ Enclosures: original (undated newspaper clipping from Mainzer fournal of 22 August 1874) and translation of a proclamation by the Bishop of Mainz with respect to the celebration of the victory at Sedan, dated ig August I874. 
and which, it is intended, shall sooner or later be that of the whole Confederation. ${ }^{59}$

Of the Southern States of Germany, Baden has taken the lead in adopting the new coinage, and will shortly be followed by the Grand Duchy of Hesse.

It is as yet doubtful when Bavaria and Wurtemburg will follow the examples.

Herr Hofmann is anxious to fix the first day of next year for the change in Hesse, and the only difficulty in doing so appears to arise from a fear lest the period between this and the commencement of the year may not suffice in order to supply small coin for general use in large quantities enough.

It is very probable, however, that the Prussian mint will aid the operation: as, apart from the fact that the heterogeneous nature of the currency in Germany (varying as it does so essentially in the different States) is an acknowledged evil, Prussia will be anxious to accelerate a further step in the Unification of the whole Country in so important a matter.

It is objected in Southern Germany that the change of currency will have the effect of raising prices by one seventh, or in other words: that whereas at present one gulden (or sixty Kreutzers) is paid for an object, the same will in future, cost two marcks (or 7o Kreutzers).

In view of the projected change, the Hessian Government have already raised the salaries of their officials throughout the Grand Duchy by one sixth as a partial relief.

All monetary innovations must necessarily be attended by some degree of inconvenience; but it has been less felt in the present instance in Prussia, where the transition from thalers to marks is an easy one, as the thaler exactly equals three marks.

$[\ldots]$

[P.S.] Since writing the above an official intimation has been published in the Darmstadt paper to the effect that the German Imperial Currency will on the first of next year be adopted in the Grand Duchy of Hesse.

I enclose copy and translation of the notification. ${ }^{60}$

\footnotetext{
${ }^{59}$ The Mark was established as the common German currency - based on the gold standard - by the imperial laws of 4 December I87I and 9 July I873. Corresponding ordinances were issued in Prussia on 28 June 1874 and in Baden on 17 and I9 July I875. In both states the Mark was introduced on I January I875. Württemberg followed on I July I875 and Bavaria, as stipulated in the imperial law of 1873 , on I January I876.

${ }^{60}$ Enclosures: original (undated newspaper clipping from Darmstädter Zeitung of 2 September 1874) and translation.
} 


\section{FO 30/244: Francis Clare Ford to Earl of Derby, No 5, Darmstadt, 12 February 1875}

[Received I5 February by messenger to Cologne. For: The Queen / Disraeli / Circulate; $\mathrm{D}[\mathrm{erby}]]$

Error in The Times with respect to Englische Fräulein in Hesse

In the Times Newspaper of Friday the $5^{\text {th }}$ instant a Correspondent ${ }^{6_{1}}$ telegraphed from Paris a translation of an announcement that had appeared in the "Cologne Gazette" of the $3^{\text {rd }}$ inst. to the effect that:

"I7 Englishwomen had been released from their engagements as teachers in the public elementary schools of the Grand Duchy of Hesse."

This translation is a perversion of the Truth, it not being in any way a question of Englishwomen.

The fact is a religious Community of very ancient origin does exist in the Grand Duchy termed the "Englischen Fräulein" the members of whom have been in the habit of teaching in the Common schools of the Country. ${ }^{62}$

It being, however, one of the principles of the new Hessian School $\mathrm{Law}^{63}$ that persons belonging to religious societies and orders should be employed as little as possible as teachers, and as the Government has succeeded in procuring the services of $\mathrm{I} 7 \mathrm{in}[\mathrm{s}]$ tructress' not belonging to any religious Society or order, a corresponding number of the "Englischen Fräulein" were notified that their Services as teachers would no longer be required.

The Paris correspondent to the Times translated "englischen" into English, whereas the Correct rendering of the word should have been 'angelic'.

'Englisch' used in German as an adjective has the signification of 'angelic', and the term "Englischen Fräulein" and "Engelschwestern" or angel sisters is used indiscriminately.

Goethe when he put the following words;

"und lispen [sic] Englisch, wenn Sie lügen"

into Wagner's mouth, whilst talking to Faust, certainly did not wish to cast a slur on the veracity of Englishmen.

\footnotetext{
${ }^{61}$ Possibly Henri Opper de Blowitz.

${ }^{62}$ The Englische Fräulein (Institutum Beatae Mariae Virginis) was the name of a religious congregation of women, originally founded by Mary Ward in I6og.

${ }^{6}$ Hessian School Law of I6 June I874. According to Article 38 members of religious congregations were prohibited from teaching.
} 
The line translated into English was thus:

"and they (speaking of Spirits) lisp angelically when they lie" [.] ${ }^{6+}$

\section{FO 30/244: Hubert E. H. Jerningham to Earl of Derby, No 19, Darmstadt, ir May 1875}

[Received I4 May by post. For: The Queen / Prince of Wales / Disraeli / Circulate; Qy: Paris / Berlin; D[erby]]

Hofmann's deep-rooted conviction that another war with France is necessary

$\mathrm{M}^{\mathrm{r}}$ Hofmann, who as Your Lordship is aware, is looked upon in this Country rather as the trusted agent of Prince Bismarck than the independent Prime Minister of Hesse, and whose opinions and conversation derive on that very account a greater interest than they would otherwise possess, spoke to me very openly this morning on the subject of the letter published in the Times newspaper of the $5^{\text {th }}$ Instant respecting the likelihood of a new Franco German war. ${ }^{65}$

His Excellency's language contrasts in so marked a manner with the studied articles in the Hessian and Baden press generally which endeavour to allay the fears raised by the letter in question, that I deem it my duty to report the conversation to Your Lordship.

$\mathrm{M}^{\mathrm{r}}$ Hofmann began by expressing his conviction that a war with France "was not only inevitable but necessary"; and that the only "question was who was to begin it? That the French wished it, he had no doubt: that they would undertake it shortly he did not believe, as they were not prepared; but could they only find sufficiently powerful allies, he did not think that their aggression would be dependent upon their state of preparation."

"This" added the Minister "is a fact palpable to all and mostly to those interested in the matter, viz to all Germany."

"Such being the case, and the revenge of France being only a question of time, was it not a necessary and fatal political duty incumbent upon the Government of the German Empire to parry the blow they saw being prepared for them, by a bold thrust given in time?"

To my remark that I thought it rather doubtful whether the justice of any Country would acquit the man who armed to the teeth, should assault the convalescent victim of his former blow, because of the

\footnotetext{
${ }^{64}$ Johann Wolfgang von Goethe, Faust: Eine Tragödie (1808), line II4I.

${ }^{65}$ For the letter published in The Times of 6 May 1875 (not 5 May as stated in the dispatch), see n. 216 in Berlin section.
} 
possibility of this former victim getting strong again, His Excellency replied "that undoubtedly it might not be a very moral act, but it certainly was one dictated by policy; and in some cases policy might be deemed a moral virtue when it concerned the welfare and security of millions."

"Were he, Prince Bismarck, he would naturally be overwhelmed by the huge responsibility which such a position entails; but while guarding to the utmost against placing his Country in the wrong, he most decidedly would not shrink from the duty of considering how far he was justified as Head of the Government of the Country in allowing a neighbouring nation time and the opportunity to become powerful knowing that nation's efforts to be directed against his own Fatherland."

"France" continued $\mathrm{M}^{\mathrm{r}}$ Hofmann "is sufficiently intelligent to know and understand this. She is still sufficiently unprepared to dread the realisation in Germany of the position her daily increasing power is creating: hence the expression of that fear in the "Scare letter" to the Times, and which, if written at all by a Frenchman, ${ }^{66}$ reads like an appeal to other Powers to take pity upon her. It is quite true, said $\mathrm{M}^{\mathrm{r}}$ Hofmann, that the possession of Belfort by France is not looked upon with favour in Germany, and it is of public notoriety, added he, that General v Moltke was very much against the cession of it, which Prince Bismarck had urged.$^{67}$ It is not to be wondered at therefore, if such a bone of contention occasionally gives rise to a fear on the part of those now enjoying it, lest those who could have retained it should feel inclined, as a matter of security, to reclaim it when the opportunity offers."

Such plain language needs no comment, but Your Lordship will gather from the fact of its unmistakable plainness that the projects at Berlin are being slowly and surely matured throughout Germany and nothing shows this so much as the kind of training to face any eventuality which the people go through at the voice of their leaders, a specimen of which the above reported conversation may fairly be considered to be.

It is an undeniable fact, I believe, that while peace is not only ardently longed for by, but is vitally necessary to Germany, the Germans one and all believe in the necessity of a second war with

\footnotetext{
${ }^{66}$ The author, Henri Opper de Blowitz, was a naturalized French subject of Bohemian descent.

${ }^{67}$ According to The Times, German plans included the annexation of Belfort, which under the terms of the Treaty of Frankfurt of io May I87I - had remained French. This was in recognition of French resistance during the I03-day siege of Belfort in the Franco-Prussian War of $1870-187$ I.
} 
France before a lasting peace can be obtained: and this belief has been fostered by the authorities until it has reached the degree of conviction, and acts depressingly upon the commercial welfare of the nation.

There is a second notion which the Germans are less ready to admit but which comes out forcibly in conversation with them, and is a sign of their innate dread of the French, notwithstanding their contempt for French frivolity "leichtsinnigkeit": that is, that a second war with France must be undertaken while those Generals are alive who have made Germany great. "Generals not armies win a war["] is a prevalent notion deserving of attention.

If from the people one turns to the Government, Your Lordship will hear from better sources how necessary it is to drown home troubles; even if it be in the more open though not less dangerous sea of foreign wars; and will gather on the whole that if $\mathrm{M}$ de Bismarck is the hope of his country, he is not the less its bugbear.

\section{FO 30/244: Hubert E. H. Jerningham to Earl of Derby, No 23, Baden Baden, 3 June 1875}

[Received 7June by messenger to Cologne. For: The Queen / Disraeli / Circulate; D[erby]]

Political programme of the German Social Democrats; alliance of Ultramontanes with Socialists against Bismarck

I have the honor to enclose in original the political programme of the German Social Democrats and to accompany the same by a translation. ${ }^{68}$

There is nothing in the general plan with which Your Lordship is not already acquainted, and the ultimate end of destruction of property is not the less clear for being screened by such specious arguments as the equal distribution of work and of the profits resulting from it.

One point, however, not mentioned in this programme, but to which Your Lordship's attention has no doubt already been called, is so peculiar to Germany at present, that I would fain bring it again to your notice.

The phenomenon is no other than the circumstance which has brought two essentially different elements like the Ultramontane and

\footnotetext{
${ }^{68}$ The so-called Gotha Program was adopted by the Socialist Workers' Party of Germany (a merger of the Sozialdemokratische Arbeiterpartei Deutschlands, and the Allgemeiner Deutscher Arbeiterverein) at its founding congress in Gotha (22 to 27 May 1875). Enclosures: undated newspaper clipping (Programm der sozialistischen Arbeiterpartei Deutschlands) and translation.
} 
Socialist parties to unite for a time against the dictatorship of the present German Chancellor.

The fact is all the more to be wondered at, that in reality no possible reliance can be placed in such a purely temporary understanding.

The Ultramontanes in general have perhaps as great a dread of Socialism in every shape, as the social democrats as a rule have distaste for religion under any form: but while the one apprehend a supremacy hostile to religious interests, the other dread a Government other than that of the people; and thus it naturally follows that fear is the common basis of the present alliance.

M. de Bismarck's hostility to religion and his real or apparent tyranny have encouraged this fear out of which opposition to him has been born, and he may thank himself for having achieved among other wonders an understanding so extraordinary and which must fall the day he ceases to be powerful.

This being understood, it is not a matter of surprise that in elections to the Reichsrath, ${ }^{69}$ Ultramontanes have won their seat through democratic votes, in places where neither party being strong enough to return their own Candidate, they had to unite their forces so as to beat the supposed supporters of the German Chancellor, and vice versa.

The Germans in office are generally loath to admit the increasing power of the democrats; and the Ultramontanes are still shy of being seen in such company; but the working classes are every day prouder of their democratic numbers and each day's story of unnecessary vexations lessens the disinclination of the Ultramontanes to work with their Socialist brethren in their opposition to the common enemy.

Thus distrust of, has replaced the former confidence in the Great man at the head of the German Government, and the change has not been beneficial to the cause of monarchy.

Indeed it is a question whether the silly war waged against a few old and powerless prelates, while it has failed to reap for the authors more than humiliations at the hands of their victims, has not seriously compromised the great end which the late war had almost realised - the merging of all interests in one great aspiration for a united Germany.

The Alliance of Ultramontanes with Socialists is at least a proof that matters are at their worse in this unfortunate country, if it is not a kind of justification why those who have created this state of things should sometimes like to drown the ugly present in a more hideous "future".

\footnotetext{
${ }^{69}$ The last elections to the Reichstag were held on Io January I874.
} 


\section{FO 30/244: Hubert E. H. Jerningham to Earl of Derby, No 37, Private, Baden Baden, 5 October 1875}

[Received 9 October. For: The Queen / Disraeli; Qy: Paris / Berlin; F.S.S. [Francis S. Stephens]; D[erby]]

Conversation with emperor about French war scare

In the course of a conversation with which I was honoured last night at a party given in his honour by the Duchess of Hamilton, the Emperor of Germany ${ }^{70}$ gave utterance to a sentiment which appeared to me so singular, considering that nothing in the remarks that preceded it, had called for its expression, that I venture to bring it to Your Lordship's notice.

His Majesty had asked me whether in the course of my diplomatic career I had been attached to the Paris Embassy, and on my reply in the affirmative, the Emperor said: "Pourvu que ces Français ne pensent plus à une revanche." ${ }^{\prime 1}$

Were it not for the fact that such a sentiment points to the groove of ideas wherein His Majesty's Advisers appear to be anxious to keep the Imperial mind, I would apologise for reporting that which every other German one meets, is prone to utter in the same words every day of the week.

But if Your Lordship will remember how, in my despatch $\mathrm{N}^{\circ}$ I9 of II $^{\text {th }}$ May last, ${ }^{72}$ I endeavoured to show the dictated and studied language of the German Chancellor's trusted Agent in Hesse, and the tone of conviction with which that Agent, $\mathrm{M}^{\mathrm{r}}$ Hoffmann [sic], spoke of the revenge of France as a question of time only, you will understand the importance I attached to the remark of the Head of the Empire, when I found it to coincide with the ideas of his subjects, and the motives, therefore, which prompt me to report His words though the conversation had not the slightest official character.

The tone besides with which the words were uttered added a certain importance to the meaning of the sentiment.

An emphasis upon the first word showed the bent of the Imperial mind, dreading perhaps the necessity of a second war, and yet alive to its possibility, should the wild expressions of an imprudent press at any time, make such a misfortune the condition of peace in the Emperor's territory.

\footnotetext{
${ }^{70} \mathrm{En}$ route to Italy Wilhelm stayed at Baden Baden from 29 September to I6 October I875.

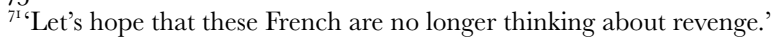

${ }^{72}$ See pp. 217-219.
} 
The slight national conceit of which the Emperor gave at the same time an instance in this remark, adds perhaps to its interest.

\section{FO 30/244: Hubert E. H. Jerningham to Earl of Derby, Secret, No 43, Darmstadt, 28 November 1875}

[Received ${ }_{4}$ December by post. For: The Queen / Disraeli / Circulate / Berlin; D[erby]]

Decline of Hessian independence; short history of the Grand Duchy and its political doings since I866

Although I approach the subject with great diffidence, still I think it my duty to point out to Your Lordship, as far as I am able, how it is daily becoming more evident that the independence of the Grand Duchy of Hesse is an absolutely nominal one, and that this state of things may lead sooner than is expected to ideas of absolute incorporation on the part of Prussia.

Indeed a very simple survey of the facts which have come to pass since the war of Germany with France, and the altered position which that war has created to Hesse, are enough to show that its annexation to Prussia is a logical result of the success \& policy of that country.

A little more reflection shows that the powerful protection of Russia, (whose Empress ${ }^{73}$ is sister to the reigning Grand Duke of Hesse), and the friendship of the two Emperors of Germany and Russia, are the only guarantees of independent sovereignty possessed by the Grand Duke, while they constitute the only obstacle which Prince Bismarck cannot drive sternly and roughly over.

Before the year I866 the Grand Duchy of Hesse possessed a geographical advantage which made her vote in the Diet ${ }^{74}$ one of very great importance, separating as she did the Palatinate from the Mother Country, Bavaria, and the Grand Duchy of Baden from the Kingdom of Prussia.

She was moreover the possessor of that bank of the Rhine which was so coveted by France, and on whatever side Hesse voted, she must carry the majority.

The war of $1866^{75}$ came, and only changed the physiognomy of those who had formerly courted the favours of the Grand Duchy; for, when the victors perceived, that powerful Imperial protection was at hand to prevent the total incorporation of Hesse into the Kingdom of Prussia, the North German Confederation endeavoured to supplant

\footnotetext{
${ }^{73}$ Maria Alexandrovna.

${ }^{74}$ Diet of the German Confederation (I8I5-I866).

${ }^{75}$ Austro-Prussian War of I866; the Grand Duchy of Hesse sided with Austria.
} 
the hitherto successful Austrian influences, and postponed the doom, which has not, however, been lost sight of.

The war of 1870 did away with the frontier character of the Grand Duchy, and lost her the only remaining geographical prestige she possessed.$^{76}$

Surrounded by Prussia on all sides, having been previously beaten by her into submission, the Country was glad to pay the exemption from total annexation, by a voluntary resignation of all its former ambition and privileges, for the sake of the great Fatherland of Germany, which screened the smaller Fatherland of Prussia that put the high sounding name ${ }^{77}$ forward, and reaped the reward of its adroitness.

The nation was not sufficiently recovered from its old Austrian sympathies to side at once with its new masters, and a party therefore had to be formed, which became the National Liberal party ${ }^{78}$ and which, without offending the notion of Hessian loyalty to the Grand Duke, should fire the enthusiasm of the people for German unity, under cover of which pretext, though in most instances with perfect good faith, it worked in the interest of Prussia, and of the policy her great Master ${ }^{79}$ had found necessary to adopt to gain success in Southern Germany.

This party, the result of a successful war in the cause of German Unity, naturally killed any Hessian national party that had existed before, and it became necessary to select chiefs to guide its enthusiasm and control its ardour, lest the cooling down of Imperial aspirations should bring the reality too soon and too clearly to view.

Herr von Dalwighk was replaced by Herr Hofmann who sometime before had acted as his Secretary, and had latterly been employed at Berlin $^{80}$ under the Chancellor who had noticed his quick apprehension of subjects and his valuable talents as the expounder of other people's thoughts.

To him was entrusted the great mission of endeavouring to work down the animosity of the Hessians generally for the Prussian name, by the instrumentality of the National Liberal party, and under the colour of German patriotism.

\footnotetext{
${ }^{76}$ Initially only the northern part of the Grand Duchy, the province of Upper Hesse (Oberhessen), belonged to the North German Confederation. On I5 November I87o the Grand Duchy joined the Confederation in its entirety (see n. I5 in this section).

${ }^{77}$ 'German Empire'.

${ }^{78}$ The National Liberal Party was founded in I867; in Hesse the National Liberals kept the name Fortschrittspartei (founded in I86r).

${ }^{79}$ Otto von Bismarck.

${ }^{80} \mathrm{Karl}$ von Hofmann was Hessian envoy to Berlin and plenipotentiary at the Federal Council (Bundesrat).
} 
The despatches marked in the margin, which I had the honour to address to Your Lordship's predecessor in office and to yourself in the years 1873 and 1874 and 1875 will show you how $\mathrm{M}^{\mathrm{r}}$ Hofmann set to work to his task with all the earnestness of a blind believer in the power and policy of the German Prime Minister.

The Prussian Education system was substituted after much difficulty, to that which formerly gave the Hessian Parents a remnant of authority over their children. ${ }^{81}$ [Note in margin: ' $\mathrm{N}^{\mathrm{o}} 3$. Aug ${ }^{\mathrm{t}}$ I873']

The encouragement given at the outset to Bishop Reinkens and his absurd sect, which the Bishop of Mayence ${ }^{82}$ once cleverly denounced as "diese infame Bismarckerei" ${ }^{3}{ }_{3}$ was the prelude of the alliance of this Country with Prussia in its individual struggle against the Papacy and its followers, and led to his recognition. ${ }^{84}$ [Note in margin: ' $\mathrm{N}^{\mathrm{O}} 7[$. Sept: I2. I873']

The assimilation of Evangelical doctrines throughout Prussia was followed by a Bill presented by the Hessian Government for a similar object in the Grand Duchy. [Note in margin: ' $\mathrm{N}^{\circ}$ i r. Oct 4. I873'] ${ }^{8_{5}}$

The abolition of responsible Ministers, and the centralization of power in the hands of one minister, exalted the position of the Chancellor's trusted Agent while it led the way to the natural \& national cry that direct Government is better than that through substitutes. ${ }^{86}$ [Note in margin: 'No ${ }^{\circ} 4[$.$] Oct 21. I873']$

Civil marriage was declared to be compulsory throughout Hesse, in anticipation of a law to that effect which was carried shortly after in the Prussian Landtag. ${ }^{87}$ [Note in margin: ' $\mathrm{N}^{0}{ }_{1} 6$ [.] Nov 4. I873'] $^{\text {' }}$

The election of a president ${ }^{88}$ of the Hessian Chambers was made the means of obliging the Grand Duke to submit his will to that of the National Liberal Party by forcing him to elect the man of their choices, and thus lessening his prestige in the eyes of his people and especially of their Representatives. [Note in margin: ' $\mathrm{N}^{\circ}$ 2. June 4. I874']

\footnotetext{
${ }^{81}$ Jerningham is referring to the Hessian School Law of I6 June I874.

${ }^{82}$ Wilhelm Emmanuel von Ketteler.

${ }^{83}$ 'This disgraceful Bismarckism'.

${ }^{8}$ Reinkens was officially recognized by Hessian authorities on I $_{5}$ December 1873 . For the Old Catholic movement, see n. 36 in Berlin section.

${ }^{85} \mathrm{Jerningham}$ is referring to the statutory provisions for parishes and synods in the 6 eastern provinces of Prussia of Io September I873, and the Hessian church constitution of 6 January 1874 .

${ }^{86}$ In his dispatch No I4 of 4 October I873 Jerningham interpreted the abolishment of the title of minister of finance as the beginning of centralization in the grand ducal government.

${ }^{87}$ On 4 November 1873 the second chamber of the Hessian Landtag voted in favour of compulsory civil marriage. The Prussian bill on civil marriage was passed on 23 January I874; it served as model for the imperial law of 6 February 1875.

${ }^{88}$ Joseph Görz.
} 
Lastly the law regulating the relations of the Church and of the State, through an amendment of the Falk laws, brought the hated Bishop of Mayence within the Scope of avenging authority, while it dealt in Hesse the same severe blows that it did in Prussia upon the Catholic subjects of that Kingdom. [Note in margin: ' $\mathrm{M}^{\mathrm{r}}$ Ford $\mathrm{N}^{\mathrm{o}}$ I7[.] of 28. April I875' $]^{89}$

As Your Lordship perceives, these measures when compared with those passed in the Prussian Chambers savour of a steady and uniform policy, ably carried out by the Agent ${ }^{90}$ of the Minister ${ }^{91}$ who conceived it.

Had that policy been truly \& honestly German instead of palpably Prussian and sectarian, the first object it had in view of uniting all Germans in one bond of friendship and under one system of impartial and beneficial laws would have been hailed with enthusiasm, and would have produced results very different to those evident, in the two Grand Duchies ${ }^{92}$ at least, of which I am entitled to speak.

As it is, the ultimate object of Prussia is palpable to the most blinded, and the love of Germany which is unquestionable, is not yet strong enough to drive the distaste of Prussia from the thoughts of the people.

Prussian ambition has oozed out notwithstanding the effort to hide it.

A more practical turn is given to these rather sentimental feelings, (tho' in the case of I 8 million Catholics of the Empire these feelings are acutely painful) by a glance at the commercial downfall and nullity of a country which should through its resources and its population become a prosperous little State. [Note in margin: 'Com ${ }^{\text {[Commercial] }}$ $\mathrm{N}^{\mathrm{o}}$ I. Sept 3. $\left.1875^{\prime}\right]$

As it is, the value of imported goods exceeds yearly that of the exports by nearly $35 \%$, and while the Country pays taxes which are raised every recurring financial period to face an increased expenditure caused by the increased price of living, the most prolific sources of revenue such as those derived from telegraphs, postage, stamps and Customs are paid into the Imperial or in other words the Prussian treasury.

If then it be borne in mind that the Hessian child is educated under a Prussian system - that when old enough to serve, he becomes a soldier in the Prussian army - that the Grand Duke of Hesse cannot promote his own subjects in his own nominal army - that the army is

\footnotetext{
${ }^{89}$ Jerningham is referring to the 5 Hessian Church laws of 23 April I873; for the Prussian Falk or May Laws, see nn. II2 and I40 in Berlin section.

${ }^{90} \mathrm{Karl}$ von Hofmann.

${ }^{91}$ Otto von Bismarck.

${ }^{92}$ Baden and Hesse.
} 
paid from Berlin - that the public offices are under Prussian tutelage that the clergy is subject to Prussian laws - that the principal revenues of the country revert to Berlin - that the Legislative Chamber is made up of a Prussian party - that its leader, who is at the same time the sole Minister of Hesse, is an Agent of Prussia; the question must force itself to the mind: what is the independence of the Grand Duchy? Where are the Grand Duke's sovereign rights and when will this abnormal state of things come to an end?

It lies not with me to say when the total annexation of this Country is to take place, but I have deemed it my duty to show Your Lordship, though very feebly, how logically impossible it is for this Grand Duchy to maintain an independence which at present is so purely nominal, and which indeed is probably dependent on the life of the present Grand Duke only, unless any political event arises to make it advisable on the part of Prussia to annex Baden and Hesse, even more promptly than it can yet be anticipated.

\section{FO 30/244: Hubert E. H. Jerningham to Earl of Derby, Secret, No 44, Darmstadt, 10 December 1875}

[Received i3 December by messenger to Cologne. For: The Queen / Disraeli / Circulate; $\mathrm{D}$ [erby]]

Proposed increase in Prince Ludwig's income postponed by dissatisfied chamber; Ludwig to become heir presumptive rather than heir apparent

The Hessian Chambers separated a few days ago, ${ }^{93}$ having voted the Budget in principle, and thus empowered the Government to collect taxes for the purposes of the revenue, but reserving to a future session the discussion of several of its provisions.

The proposed new tax upon incomes derived from shares and invested stock of all kinds has dissatisfied even the passive majority which the Government commands in the Chambers, and hence it was considered more prudent to defer to another time the proposed increase in the grant upon the Civil list made to His Royal Highness Prince Louis of Hesse, Consort of Her Royal Highness Princess Alice of England, and to which I referred in my despatch $\mathrm{N}^{\mathrm{o}}$ III Commercial of the $22^{\text {nd }}$ ultimo. $^{94}$

${ }^{93} \mathrm{On} 27$ November 1875; the budget for the first six months of 1876 was approved on 26 November.

${ }^{94}$ In his No 3 Commercial of 22 November 1875 Jerningham noted that a proposed supplementary grant of $£_{1}$ I57 r would raise Prince Louis' income from the state from $£_{3429}$ to $£ 5000$ per year. 
If such a step has been deemed prudent on the part of a Government commanding a majority of 48 out of 50 members in the Lower House, it very strongly points, at the same time, to that spirit born from the nature of things, which I endeavoured to expose to Your Lordship in my preceding despatch $\mathrm{N}^{\mathrm{O}} 42 .{ }^{95}$

The power of the national party has lessened that of the Hessian Monarchists, and a simple call for an exhibition of proper and loyal feeling towards the members of the Hessian House, is no longer enough to insure a response on the part of the Legislative Chambers.

The members of the Grand Ducal Family are fully aware of this, and have, I understand on good authority, resolved a short time since upon abiding entirely by the letter of the Constitution ${ }^{96}$ which makes the Grand Duke's next brother his heir apparent in the event of his having no children.

It was long supposed that His Highness Prince Charles of Hesse who is very infirm and of any but an ambitious temperament wished to resign his right to the Grand Ducal Throne in favour of his eldest son, His Royal Highness Prince Louis: but if there was at any time a foundation for this supposition, the case is altered now.

There are not wanting those who believe that Prussian influence has been at work, (the wife ${ }^{97}$ of His Highness Prince Charles, being a Prussian Princess) so as to lessen the difficulties which might possibly arise with England, should an English instead of a Prussian Princess be on the Grand Ducal throne, at the time when, in the interest of Germany, it is deemed a wise step to mediatize the Hessian family as so many Royal German Houses have been before them.

These are mere speculations which I only report to Your Lordship because they are symptoms of the times, and as such, are interesting to note.

In my belief, however, the real reason for the decision of His Highness Prince Charles is that by his accession to the Grand Ducal throne he will become enabled to settle in the future an income upon his younger sons ${ }^{98}$ which would be raised in proportion to their increased rank as children of the Sovereign, and above all to secure to his wife, should she survive him, a position and means which could never be overlooked.

\footnotetext{
${ }^{95}$ Jerningham is referring to No 43, 28 November i875; see pp. 222-226.

${ }^{96}$ Article 5 of the Constitution for the Grand Duchy of Hesse of 17 December 1820.

${ }^{97}$ Elisabeth.

${ }^{98}$ Heinrich and Wilhelm.
} 


\section{FO 30/245: Hubert E. H. Jerningham to Earl of Derby, No I, Darmstadt, I January 1876}

[Received 3January by messenger to Cologne. For: The Queen / Disraeli / Copy to Council Office; D[erby]]

Anticipated political acceptance of new education bill; influence of Bismarck increasingly evident in south German politics; reduction of clerical authority incurs popular hostility

I have the honour to enclose in original and in translation a project of law which will shortly come for discussion before the Baden Chambers, and which in any other less one sided House of Parliament would probably excite a deal of interest, as it strikes a death blow at the hitherto existing Elementary denominational school. ${ }^{99}$

Baron de Freydorf, however, anticipates very little difficulty in passing the Bill through the Lower Chambers, and it is not easy to see how he should entertain any apprehension whatever when his party commands a majority of 47 upon a total house of $5^{\circ}$ members.

According to the law of March 8. I868, public Elementary Schools in the Grand Duchy of Baden are based upon the Commune and are governed by the municipal authorities in the Commune.

By the present law the State intends to take a more direct part in their management, and while it does not go the length of imposing religious teachers of a different denomination to that of the majority of the scholars, still it does away altogether with existing denominational schools in parishes, and levels the various religious denominations by causing each to be represented on the local School Board irrespectively of their number.

It is clear that in a country like Baden where the Catholics represent two thirds of the total population, the few clauses above alluded to are likely to prove an unfair piece of legislation, which the specious argument of Baron de Freydorf that the Government cannot legislate for a particular sect but for all denominations at once, is not powerful enough to justify.

My remark that a school Board such as the Government contemplate might aptly represent the various sects in the land, but not the number each of them could boast, was not met by the Baron with any other more forcible reply than that all religious denominations should have a fair chance of expressing their opinion on the question of education.

\footnotetext{
${ }^{99}$ Enclosure: Beilage zum Protokoll der 5. Öffentlichen Sitzung der 2. Kammer vom 3o. November ${ }_{18} 75$ (translation missing in $\mathrm{FO} 30 / 245$ ). The law, which made non-denominational schools compulsory, was passed by the Baden chambers on 6 May and 22 June I876; it came into effect on I8 September 1876 .
} 
Were it not for the fact that in each move of the Governments that constitute Southern Germany, the influence of the Prussian Chancellor ${ }^{100}$ is visible, it is doubtful whether the prevalent tendency to reduce by every means the authority of the clergy, in the range of thought and of teaching would attract so much notice, but the hostility is so great that as the effects of it break out in one place after another, it becomes interesting to note how united Germany is gradually being disunited by the very man who made her one.

\section{FO 30/245: Hubert E. H. Jerningham to Earl of Derby, No 2, Darmstadt, 3 January 1876}

[Received 7 January by post. For: The Queen / Disraeli / Circulate; D[erby]]

Conversation with Hofmann and Prince Alexander regarding precarious financial state of Hesse

In my despatch $\mathrm{N}^{\circ} 3$ Commercial of the $22^{\text {nd }}$ of November last and $\mathrm{N}^{\circ} 42$ secret of the $28^{\text {th }}$ of that same month, I called Your Lordship's attention to the financial difficulties of this country, and drew conclusions adverse to the maintenance much longer of an independence already nominal. ${ }^{101}$

A conversation which I had this morning with both $\mathrm{M}^{\mathrm{r}}$ Hofmann the Minister for Foreign Affairs and His Highness Prince Alexander of Hesse, brother to the reigning Grand Duke, so fully confirms the views which I ventured to express, that I must needs report its substance, that Your Lordship may judge how in Ministerial and Royal Quarters here, a sense of despondency has overtaken those who lately were so sanguine that the doom of the smaller States in Germany was further off than it is.

$\mathrm{M}^{\mathrm{r}}$ Hoffmann [sic] candidly acknowledged that he had obtained for his ordinary Budget the small surplus of $f_{125}$ at the cost of fresh taxation only, and had covered his Extraordinary expenditure by drawing upon the Balance remaining out of the Indemnity money. ${ }^{102}$

"Half the amount of that fund has already been expended," said His Excellency, "and what are we to do when it is entirely so?"

"The very taxes we are obliged to raise, offend the party on whom we rely to carry them through, and the Imperial laws by which we

\footnotetext{
${ }^{100}$ Otto von Bismarck.

${ }^{101}$ Jerningham is referring to No 43, 28 November 1875; see pp. 222-226.

${ }^{102}$ The Hessian share of the French war indemnity (see n. IO7 in Berlin section) was $9 \cdot 3$ million thalers.
} 
are tied forbid our raising the indirect taxes which might save our credit."

"This credit is not such as to warrant our raising loans, and were we to do so, we have no material guarantee to offer to the payment of interest and at the same time of meeting the legitimate State expenditure".

This cannot escape the notice of the Imperial authorities, and no argument for incorporation of the Smaller States into the Empire could be stronger than their financial difficulties".

This last remark of $\mathrm{M}^{\mathrm{r}}$ Hofmann struck me very forcibly, knowing it to be the expression of one who had worked heartily in the cause of the unification of Germany, and had brought his own country to this pass, but who felt that he has been somewhat prematurely outdone by the party he has so long guided and of which he is still the nominal leader.

His Highness Prince Alexander was more outspoken still, and said he did not understand how it was that Hesse which had always been so prosperous financially speaking, was now in such a bad condition.

"I know" said His Highness "that the aim of the National Party is to mediatize the few remaining sovereign Princes in Germany, and that their most powerful lever in this work of destruction is the argument, that under the Empire people would pay less taxes than under a separate state in that Empire: but how are we to combat a party with such a majority in our Parliament; and how are we to convince the people of the reverse?"

Your Lordship may gather on the whole, that the great policy which made Prussia work her own ends by means of the magic words, German Fatherland, is fast reaping its fruits; though the hour of victory will cost her perhaps the loss of her own proud name, in the general merging of all German States in a final German speaking Empire.

\section{FO 30/245: Hubert E. H. Jerningham to Earl of Derby, No II, Darmstadt, 3 February 1876}

[Received 7 February by messenger to Cologne. For: The Queen / Disraeli / Circulate; Qy: Berlin; D[erby]]

Imprudent speech by Hofmann in Reichstag; possible ramifications in Hesse

At the Sitting of the Bundesrath of the $28^{\text {th }}$ ultimo at Berlin, $\mathbf{M}^{\mathrm{r}}$ Hofmann, the Prime Minister of Hesse made a speech which lost

\footnotetext{
${ }^{103}$ According to Article 35 of the imperial constitution the Empire had the exclusive right to legislate customs as well as the taxation of salt, tobacco, sugar, and - with the exception of Bavaria, Württemberg, and Baden - of brandy and beer.
} 
the cause he was deputed to defend; proved once more the truth of the saying that the wisest people often say the silliest things; and has raised a regular storm of indignation in this Country which may have disagreeable results. ${ }^{104}$

When paragraph I3o of the new Penal code relating to the Social Democrats had been unanimously rejected, although presented to the House by Count Eulenburg, $\mathbf{M}^{\mathrm{r}}$ Hofmann rose to propose the adoption of Article I3I which proposes to deal with political and religious agitators and is specially levelled at the Ultramontanes.

His Excellency pleaded his cause with so much earnestness that he was called to order by Herr von Forckenbeck, the President, for insulting the feelings of members of the house.

$\mathrm{M}^{\mathrm{r}}$ Hofmann somewhat startled at this unexpected turn, fell into another error, and called his observation of the Hessian Press during three years experience to witness, that in it: "the German Empire is each day represented in the most shameful manner as the Empire of sin, of knavery, of tyranny, and as sucking the blood of the people," and that in Hesse at least a paragraph such as the one proposed is indispensable to check such monstrosities.

His Excellency finished his speech by declaring that in Germany "there exists a fund of rudeness and cruelty in the people which some day, when it is thoroughly laid bare by the throwing off of the phlegmatic mantle which still covers it, will make them think the Paris Commune ${ }^{\mathrm{ros}}$ was but a harmless society in comparison[.]"

When however, $\mathrm{M}^{\mathrm{r}}$ Lasker had dealt the Hessian Minister one of his most powerful retorts, His Excellency awoke to the fact that he had been speaking in the name of the Chancellor and at once endeavoured to prove that he had given utterance to his own feelings only.

The result was the rejection of Article I3I by a great majority although it had nearly been made a Cabinet Question by $\mathrm{M}^{\mathrm{r}}$ Hofmann, and the question now is whether $\mathrm{M}^{\mathrm{r}}$ Hofmann may not suffer himself from the consequences of his imprudent speech.

The effect of this speech is really disastrous at a time when $\mathrm{M}^{\mathrm{r}}$ Hofmann is at a loss how to control the very party at the head of which he stands, and to carry the measures indispensable for his Government.

\footnotetext{
${ }^{104}$ Jerningham is referring to the debates on the amendments to the Reichsstrafgesetzbuch in the Reichstag (not the Bundesrat) on 28 January I876. Hofmann spoke after the rejection of $\S$ I $30 a$ and not, as stated, of $\S$ I30, which had already taken place on 27 January. The proposed $\S \mathrm{I} 3 \mathrm{I}$ provided for the strengthening of the existing $\S \mathrm{I}$ I I on defamation of the state. The amended § I3oa extended the so-called 'pulpit paragraph' of io December I87I (see n. 25 in Munich section) to documents that endangered 'public peace'. It finally passed the Reichstag on io February and came into effect on 26 February 1876.

${ }^{105}$ For the Paris Commune, see n. I4 in Berlin section.
} 
The attacks against the press are the less excusable that in reality Mr Hofmann has always been kindly treated, and that he can have borne in mind no other organs but the Ultramontane which have occasionally classified him among the antipapal fanatics of Germany. The prominence given to this Grand Duchy by its principal Representative in the spirit of animosity against the Empire which he supposes exists in the Country, is so important a blunder, that the present irritation of the people and particularly of the Hessian Press, against $\mathrm{M}^{\mathrm{r}}$ Hoffmann [sic] is not only quite comprehensible but almost excusable.

\section{FO 30/245: Hubert E. H. Jerningham to Earl of Derby, No 24, Darmstadt, 29 April 1876}

[Received I May by messenger to Cologne. For: The Queen / Disraeli / Circulate / Berlin; $\mathrm{D}[\mathrm{erby}]]$

Hofmann's qualities and suitability for the post of president of the imperial chancellery

In my preceding despatch of the $27^{\text {th }}$ Instant, I reported to Your Lordship the offer made by Prince Bismarck to Herr Hofmann of succeeding Herr Delbrück as Vice Chancellor ${ }^{106}$ of the Empire, and the fact that His Excellency had not yet accepted the honour.

This however is only a question of form as $\mathrm{M}^{\mathrm{r}}$ Hofmann had seen the Grand Duke before he spoke to me, and had obtained His Royal Highness' consent to his taking the appointment. I understand on very good authority that Herr Delbrück himself recommended $\mathrm{M}^{\mathrm{r}}$ Hofmann to the Chancellor as his successor, knowing him to be that which he is, a clear headed and indefatigable worker; and Prince Bismarck was all the more pleased with this selection that he could at once announce in the "National Zeitung" that the policy of which Herr Delbrück was the expression would in no ways be altered by his successor.

Although $\mathrm{M}^{\mathrm{r}}$ Hofmann has not yet sent me word of his acceptance of the office according to his promise, still, it is little matter of doubt that he will take the appointment; and if he does, the party that wish to give the Empire a more substantial character than what it at present possesses, will gain a strong ally in his person.

\footnotetext{
${ }^{106}$ On 25 April 1876 Delbrück resigned as president of the imperial chancellery; Hofmann, who confidentially informed Jerningham of Bismarck's offer on 27 April, succeeded to the post on I June.
} 
As Your Lordship is aware, all my despatches for the last three years have tended to prove that the acts of the Hessian Minister were inspired from Berlin and that $\mathrm{M}^{\mathrm{r}}$ Hofmann was in reality the trusted Agent of Prince Bismarck.

His selection, therefore, at the present time when the question of the German railways seems paramount in the mind of the Imperial Chancellor, is not to be wondered at, when that Statesman is in want of a lieutenant who shall be so thoroughly devoted to him as to become his mouthpiece, and I can but refer Your Lordship again to my despatch $\mathrm{N}^{\circ}$ i 6 of the $7^{\text {th }}$ March last, to show how the language of $\mathrm{M}^{\mathrm{r}}$ Hofmann justifies his selection for this duty. ${ }^{107}$

Again $\mathrm{M}^{\mathrm{r}}$ Hofmann has lost in this country the influence which he possessed when he was first appointed. The National party which he was to guide have broken through the limits set to them, and the personal prestige of the minister suffered from the unfortunate speech he delivered at Berlin in January, and which I reported to Your Lordship in my despatch $\mathrm{N}^{\mathrm{O}}$ II of the 3 February. ${ }^{108}$

His selection now, while it shows that he spoke under the inspiration of higher personages at that time, is a proof that these have recognised in him too devoted a follower not to reward his ardour in their cause, and have thus saved him from the eventual resignation of office which that loss of prestige in their account had made a question of time only, and which I had taken the liberty to point out in the above named despatch.

$\mathrm{M}^{\mathrm{r}}$ Hofmann is a sincere partisan of the Empire, and is a believer in the infallibility of Prince Bismarck as a Statesman; but he is an honest, straightforward man, who must please all those with whom he comes into contact, even though his personal devotion to a cause may be forgotten under his appearance of subserviency to another's will.

Your Lordship will allow me to refer you to the conversation I had with $\mathrm{M}^{\mathrm{r}}$ Hofmann last spring on the occasion of the designs of Prussia against France, and which I reported in my despatch $\mathrm{N}^{\mathrm{o}}$ I9 of the $\mathrm{II}^{\text {th }}$ May 1875 for a proof of how in Foreign matters also, the views of the new or coming-new Vice Chancellor agree with those of his master. ${ }^{109}$

Baron Starck will be Mr Hofmann's successor here; and though, it is early in the day to speak of him, it is certain that the Grand Duchy will not benefit by the change.

\footnotetext{
${ }^{107}$ In this dispatch Jerningham reported a conversation with Hofmann on the projected purchase of German railways by the Empire and pointed out Hesse's 'inclination [. . .] to follow out the dictates of Berlin' and the 'gradual feebleness of Hessian independence'.

${ }^{108}$ See pp. $230-23^{2}$.

${ }^{109}$ See pp. 2 I $7-2$ I9.
} 


\section{FO 30/245: Hubert E. H. Jerningham to Earl of Derby, No 37, Darmstadt, 4 September 1876}

[Received in September by messenger to Cologne. For: The Queen / Lord Beaconsfield / Circulate; D[erby]]

Suppression of Mainzer Journal containing slighting article about emperor

I have the honour to enclose in original and in translation an article which appeared on the $3 \mathrm{I}^{\text {st }}$ ultimo in the Ultramontane newspaper the "Mainzer Journal", and which I have had some difficulty in procuring, the original numbers containing the article having been suppressed by the authorities at Mayence so soon as the paper was issued, and a second edition having been at once printed for the subscribers with a blank space where the article had at first appeared.

I enclose a copy of this second edition which naturally excited more curiosity than the suppressed article deserved. ${ }^{\text {110 }}$ There is no doubt that the Emperor William and his policy are alluded to in the description, given according to Lactantius, ${ }^{\text {III }}$ of the insatiable Diocletian who wanted to turn every Roman into a soldier; but it is a question whether the authorities at Mayence were not rather overzealous in saddling their Emperor with a reputation, only maliciously hinted at in the article by its writer, who in common with a good many other Catholics of Germany would fain look upon themselves as the martyred christians [sic] of another Diocletian.

The article bears no stamp of cleverness: the comparison is poor, the allusions without wit, and altogether it is a pity it should have had the compliment of a suppression.

As the reaction, however, is fast setting in throughout Germany against the militarism of Prussia which is ruining the country in its commerce and its industry, all signs of it are worthy of notice, and the article in question may not only be taken as one out of many, but also as a proof that the Ultramontanes are not slow in seizing every opportunity of showing that they are not the only sufferers from the

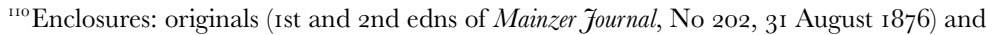
translation of article (entitled Nothing new under the sun?'). The 2nd edn of the Mainzer fournal states: 'Der diesem Raum ausfüllende Artikel: "Nichts Neues unter der Sonne?" Wurde auf Verfügung der Großherzoglichen Staatsbehörde confisciert.' (Translation: 'The article "Nothing New under the Sun?" which previously filled this space was confiscated by order of the grand ducal state administration.').

${ }^{11}$ The article alluded to ch. 7 of De Mortibus Persecutorum by Lactantius in which it is stated that 'each of the four princes [of Diocletian's tetrarchy] strove to maintain a much more considerable military force than any sole emperor had done in times past.'
} 
policy actually carried on in Berlin by "Diocletian and his Caesars", and hence ought not alone to oppose it.

\section{FO 30/245: Hubert E. H. Jerningham to Earl of Derby, No 45, Darmstadt, 30 October 1876}

[Received 2 November by post. For: The Queen / Lord Beaconsfield / Circulate / Berlin; $\mathrm{D}[\mathrm{erby}]]$

National Liberal Party put pressure on Hessian government to support purchase of railways by the empire

An incident has just taken place in the Hessian Chambers which justifies the apprehension I had the honor to express to Your Lordship in my despatch $\mathrm{N}^{\mathrm{O}} 24$ of the $29^{\text {th }}$ of April last, that the National party have broken through the limits set to them by those who are supposed to guide them.

Herr von Rabenau, a blind admirer and follower of the Imperial Chancellor, proposed a motion which was destined to elucidate from the Ministry, whether or not, they were prepared to support the Imperial proposition with regard to the purchase of the German Railways by the Empire. ${ }^{\mathrm{II}}$

Herr von Starck, the President of the Ministry to whom I spoke on the subject of this motion at the time, informed me that he hoped Herr von Rabenau would, after a conversation he had had with him, withdraw his motion and propose the order of the day, as it was unadvisable for this country to pronounce itself as yet in the matter.

Much to the astonishment of the Minister, however, Herr von Rabenau next day proposed his motion which the Chambers rejected, while, by an immense majority, they voted an amendment by Herr Hirschhorn couched in very much stronger terms and obliging the Government

I[.] to support the Imperial measure through its delegates in the Reichstag ${ }^{\text {II3 }}$

2. to direct its delegates to vote for the Imperial law, ${ }^{114}$ and 3[.] to offer the Hessian Railways for sale to the Empire.

\footnotetext{
${ }^{112}$ Rabenau's original motion concerning the implementation of Title VII of the imperial constitution is dated 2I June I876. Articles $4 \mathrm{I}^{\mathrm{I}} 47$ stipulated measures for centralizing and unifying the fragmented railway systems of the German states. The events described in this dispatch took place on 24 and 25 October 1876.

${ }^{113}$ The Ist amendment requested that the grand ducal government support the intended proposition to the Bundesrat that the Reich - according to the Prussian law of 4 June I876 (see n. 234 in Berlin section) - should purchase the Prussian railways.

${ }^{114}$ The 2 nd amendment did not explicitly refer to an imperial law but asked the grand ducal government to support any railway purchases made by the Empire.
} 
Herr von Starck was naturally taken quite unawares, and could only reply that the question not being one of immediate urgency, the Government, while certain to look to the interests of the German Empire, had not yet arrived at any decision on the question at issue[.]

It is more than probable that the Upper House will reject the motion, and thus negative the vote, but the exhibition of temper which this latter denotes, is a proof that the national party are too strong to be moderate, and too German to remain Hessians.

Herr von Rabenau, who is also a member of the Reichstag, in all probability only wished to please Prince Bismarck by obtaining the support of Hesse to a measure agreeable to the Chancellor, and was too vain to remain silent when requested.

His ill advised step, though it may give satisfaction at Berlin cannot have pleased the Grand Duke, and the evils arising out of the purchase of the Ober Hessen Railway which I pointed out to Your Lordship in my despatch $\mathrm{N}^{\mathrm{O}} 2$ Commercial of the $19^{\text {th }}$ of March last, ${ }^{115}$ have no doubt in a great measure, now that they are coming clearer, influenced the votes of the $2^{\text {nd }}$ Chamber in favour of the more advanced proposition of Herr Hirschhorn.

But the root of this increasing opposition of the National party to the exhibition of individual policy on the part of the several countries that constitute the Empire, lies much deeper.

They maintain with great justice, that an Imperial policy is the only one that cannot be tainted by jealousy, and that all the efforts of semi independent countries in an Empire to follow a policy of their own, if not likely to prove a source of discomfiture to themselves, are sure to become obstacles in the way of the great Union of German hearts which they long for.

In illustration of their sentiment on the subject, they never cease to refer to the war of 1866, when Baden, Hesse, Nassau, Wurtemberg and Bavaria each claimed a right to appoint the Commander in Chief, and each boasted of having proved better in the field: when the allies of that day, each made a separate treaty of peace, and left the weakest to go to the wall: ${ }^{116}$ when Bavaria actually revolted the German sense of patriotism of the Combatants, by declaring that soon the French

\footnotetext{
${ }^{115}$ In his dispatch of 19 March 1876 Jerningham referred to the annual payment of interests and the protection of shareholders against any further losses of the Oberhessischen Eisenbahnen.

${ }^{116}$ The peace treaties with Prussia - which insisted on separate negotiations - are dated I3 August (Württemberg), I7 August (Baden), 22 August (Bavaria), and 3 September 1866 (Hesse-Darmstadt). Hesse-Nasssau was annexed by Prussia.
} 
army would come to their rescue against Prussia, and they naturally dread the revival in any shape of such ambition and such jealousies. ${ }^{117}$

\section{FO 30/246: Hubert E. H. Jerningham to Earl of Derby, No 5, Darmstadt, I9 January 1877}

[Received 25January by post. For: The Queen / Lord Beaconsfield / Circulate / Prince of Wales; D[erby]]

Reichstag elections in Baden and Hesse; reasons for socialist progress

The elections for the Reichsrath ${ }^{118}$ have produced some unexpected results in this country and in the Grand Duchy of Baden, while they have revealed some unpleasant facts.

Out of the nine Hessian electoral circumscriptions, a second ballot has come necessary in three: viz at Mayence, at Offenbach and at Darmstadt, that is, in the three principal towns of the Grand Duchy.

At Mayence, the Ultramontane Candidate $\mathrm{D}^{\mathrm{r}}$ Moufang, tho' polling seven hundred votes more than in his successful election in 1874 , was beaten in the $2^{\text {nd }}$ ballot by a National Liberal, ${ }^{119}$ who formerly was a democrat, and who, owing to hopes of his returning to democratic views, secured the abstention of the social democrats.

At Offenbach the National Liberal Newspaper editor $\mathrm{D}^{\mathrm{r}}$ Dernburg of Berlin has to undergo on the $26^{\text {th }}$ a second ballot against the well known Socialist "Liebknecht" of Leipzig, and it is very uncertain whether the latter will not prove successful, especially after the election of a Democrat ${ }^{120}$ for the neighbouring or rather adjoining town of Frankfurt on the Main.

At Darmstadt, the national Liberal candidate ${ }^{121}$ has to undergo a second trial against a man ${ }^{122}$ of more democratic views, though no Socialist, and is almost certain of defeat.

But while the strength of the National Liberals which Hesse sends to the Imperial Reichsrath will not be materially altered, as the defeat of the opposition Candidate at Mayence is likely to be compensated by that of the National Liberal here, still it remains a fact, pregnant with significance, that one eighth of those who recorded their votes

\footnotetext{
${ }^{117}$ Jerningham is referring to von der Pfordten's attempts to win French support after Austria's defeat in the Battle of Königgrätz on 3 July I866.

${ }^{118}$ The Reichstag elections were held on Io January 1877.

${ }^{119}$ Georg Oechsner.

${ }^{120} \mathrm{Karl}$ Holthof.

${ }^{121}$ Hermann Welcker.

${ }^{122}$ Wilhelm Büchner.
} 
in the first elections where each party could rely on a candidate, are social democrats, the numbers being i 6 8or votes out of I 32987 votes, a somewhat startling revelation.

The Grand Duchy of Baden has returned National Liberals in eight out of fourteen electoral circumscriptions, but the late President of State $\mathrm{M}^{\mathrm{r}}$ Jolly, the Baden "âme damnée" ${ }^{123}$ of the Berlin Chancellor, has to fight a second election against the Protestant Ultramontane or German Conservative candidate, ${ }^{124}$ and a second ballot against a Catholic Ultramontane ${ }^{125}$ is necessary at Freiburg in Breisgau.

The social democrats, have only polled about 7000 votes in the total of 23 I 235 recorded votes or a little less than I/ $3 \mathrm{O}^{\text {th }}$, though about $25 \%$ more than in 1874 .

The great features of these elections have been[:]

I [.] the increased desire of the population to testify to their political bias, as shown by the greatly increased number of those who took part in the voting:

2. the incipient disgust for the subservient national liberals, who, more Imperial than the Emperor, hasten somewhat too rashly to throw off the cloak of their own smaller nationalities.

3[.] the growing strength and organization of the German Socialistic element, which the military despotism of Germany is daily fanning into a blaze of revolution which it will e'er long be called upon to put down, and which the ill advised internal policy of Prince Bismarck has done more to bring about, than even the bad state of trade and industry, and the absorption in military preparations of the money which might have been profitably spent among the otherwise peaceful and quiet German labouring classes.

\section{FO 30/246: Hubert E. H. Jerningham to Earl of Derby, No 13 , Darmstadt, 28 March 1877}

[Received 2 April by messenger to Cologne. For: The Queen / Lord Beaconsfield / Circulate; D [erby]]

\section{Drunken military riot in Mainz}

A drunken broil at Mayence on the night of the $24^{\text {th }}$ Instant between some Prussian and Hessian soldiers ended in the death of one of them and in several others being severely and otherwise wounded. ${ }^{126}$

\footnotetext{
${ }^{123}$ 'Henchman'.

${ }^{\mathrm{I}} 4$ Jolly lost against the Conservative candidate, Casimir Rudolf Katz.

${ }^{12}$ Leopold Neumann.

${ }^{126}$ The event in question took place on 22 March, not 24 March as stated in the dispatch.
} 
So great was the animus displayed, that the spirit of discipline which is so eminently characteristic of the German soldiery, was entirely set aside, and all the threats, commands, and advice of the officers who interfered were disregarded.

The occasion was the desire on the part of some Prussian military to take part in the amusements in which their Hessian comrades were indulging at an inn in celebration of the Emperor of Germany's $80^{\text {th }}$ anniversary.

Though incidents of this kind are not new in the fortified town of Mayence, they yet go far to show how little the system of Prussianising the Germans has any chance of success in the South of the Empire, and how great in the people is still the hatred of Prussia as a separate nation in the united Empire of Germany.

\section{FO 30/246: Hubert E. H. Jerningham to Earl of Derby, Secret and Confidential, No 25, Darmstadt, 31 May 1877}

[Received 4June by messenger to Cologne. For: The Queen / Lord Beaconsfield / Circulate; $\mathrm{D}$ [erby]]

Conversation with Prince Alexander of Hesse about his chances of ruling over Bulgaria

It having come to my knowledge that there was some intention on the part of the Emperor of Russia to benefit his brother in law, Prince Alexander of Hesse in the event of the present war $^{127}$ turning to the advantage of Russia, and the autonomy of Bulgaria in particular being secured, I availed myself this morning of an invitation to Jugenheim ${ }^{123}$ to ask the Prince in a casual way, whether he did not think it likely he would be asked to reign over the Bulgarians some day, as he had once been invited to reign over the Greeks. ${ }^{129}$

The Prince looked rather surprised, not so much at the question being addressed to him, as to its showing that a secret wish had been revealed, but he soon recovered and answered that it would altogether depend on the conditions under which he would be called upon to reign[.]

His Highness dwelt with some regret on the possibility of the Prince of Romania ${ }^{130}$ being called to the Presidency of the Trans

\footnotetext{
${ }^{127}$ Russo-Turkish War of $1877-1878$.

${ }^{128}$ Schloss Heiligenberg, Alexander's residence, east of Jugenheim.

${ }^{129}$ After the overthrow of Otto in October 1862, Alexander of Hesse was among the candidates - suggested by France - for the vacant throne of Greece; he was ultimately dismissed because of his close connections with Russia.

${ }^{13{ }^{\circ}}$ Carol.
} 
Balkan provinces, in the event of these obtaining their independence through the instrument of Russia, and forming a confederation under European guarantees.

To my remark, that, unfortunately the limits of Bulgaria were so ill defined, the Prince quickly replied that on the contrary they could not be better delineated inasmuch as the Balkan mountains formed the southern frontier, and, added His Highness, with marked emphasis, "I assure you Russia will not go further"[.] "Who knows? Sir". I know it was the decided reply.

Prince Alexander of Hesse is an amiable man, and I understand a man of business, but he can scarcely be called a clever man. His selection, (supposing his hopes to be realized) would not prove unimportant, however, as he is more Austrian than German, and more Russian than Austrian in sympathy[.]

Although the above is the report of a casual conversation, still I am disposed to attribute a certain importance to it in the future, owing to the intimate relations between the Emperor and his brother in law's family, and to the very decided pleasure the Prince took in dwelling on the reported projects.

\section{FO 30/ 246: Gharles S. Scott to Earl of Derby, Confidential, No 67, Darmstadt, 7 October 1877}

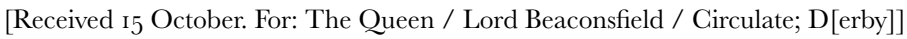

Neue Frankfurter Presse viewpoint that the German public is highly dissatisfied with England is not representative of public opinion; general feelings on Russo-Turkish War

I have hitherto hesitated to trouble Your Lordship with the comments of the local press on the present War in the East, ${ }^{1{ }^{13}}$ but an article, by it's Berlin Correspondent, in this morning's "Neue Frankfurter Presse" (a journal having a very wide circulation here) and which I have the honour to enclose herewith in copy and translation, seems to challenge some remarks. ${ }^{13^{2}}$

Although my recent arrival at this post ${ }^{133}$ does not entitle me to write on this subject with authority, yet from the little I have myself seen, and more especially from what has been communicated to me by persons who have every means of forming a correct judgment, I

\footnotetext{
${ }^{131}$ Russo-Turkish War of I877-1878.

${ }^{132}$ Enclosures: original (newspaper clipping) and translation of article (dated 5 October) in the Neue Frankfurter Presse, 7 October 1877. The name of the author could not be established.

${ }^{133}$ Scott was transferred to Darmstadt on 8 June 1877 and was acting chargé d'affaires from 7 July 1877 .
} 
venture to express my personal conviction that the sentiments of the Article I refer to are not shared by the general public, and that the statement that "the German public is more dissatisfied with England at the present moment than with every other country." - is not true of this part of the German public.

The visit of the German Emperor to Darmstadt and Carlsruhe at a time ${ }^{\mathrm{r} 34}$ when the chief topics of daily conversation were the stirring events in the East, must necessarily have had some influence on the tone of Society in these Capitals brought for the first time since the war commenced, into immediate contact with persons, if not immediately behind the scenes, at least thoroughly conversant with what is going on, and I certainly have not detected here any traces of the alleged dissatisfaction with England, or even of excessive tenderness for the cause of the Russian Arms.

On the Contrary I believe the general feeling of this Society, and of a large number of their recent visitors to be great personal sympathy with the Emperor Alexander, but little with the party which is supposed to have urged His Majesty to the fatal step of War, - severe condemnation of the manner in which the war has been conducted and of the reckless waste of human life, and profound astonishment at the manner in which the Russian Government has been misled by its agents in regard to the actual Condition and force of Turkey.

As regards the policy of the German Government I believe the general feeling here to be one of great satisfaction at the localization thus far of the present contest, and an earnest hope that continued Neutrality on the part of the German Government will enable the country to devote its energies to devising some means for alleviating the present depressed condition of German trade and industry, the causes of which fully occupy the anxious attention of some of the most enlightened German minds.

Further I am convinced that any attempt to employ the military strength of this Empire for any other object than the immediate protection of the Empire would, - to say the least of it - fail to elicit any enthusiasm in this part of Germany.

As regards the press I can only say that the views of the Frankfort "Neue Presse" are not those of the other journals which chiefly circulate in this neighbourhood: - The more official Darmstadt Zeitung confines itself to reporting and criticizing the events of the war, while the Hessian Volks blätter ${ }^{135}$ exceeds in bitter denunciations of the policy and Government of Russia accusing her not only of incapacity

\footnotetext{
${ }^{134}$ Wilhelm I visited Karlsruhe on ${ }^{6-23}$ September and Darmstadt on $24^{-25}$ September 1877 .

${ }^{\mathrm{I} 35}$ Neue Hessische Volksblätter (Darmstadt).
} 
and decrepitude military, financial and administrative, but even of systematic falsehood and hypocrisy. - The "Mainzer Zeitung' as might be expected from an organ of the Ultramontane party, loses no chance of sneering at a Government which they suppose rightly or not, to be regarded with especial tenderness by the German Emperor and Government. - The Kölnische Zeitung and the 'Augsburg Allgemeine Zeitung', so disparagingly alluded to by the Freie [Neue] Presse are also very widely circulated here, and the very able series of articles in the Augsburg journal on the internal condition of Russia and the history of the causes which have been impelling her to her present cause cannot fail to have influenced the minds of their readers in forming an opinion on the merits of the question now engrossing public attention.

\section{FO 30/247: Charles S. Scott to Earl of Derby, No 7, Confidential, Darmstadt, 16 February 1878}

[Received i9 February by messenger to Cologne. For: The Queen / Lord Beaconsfield / Circulate; D [erby]]

Feelings of press and public in regard to critical phase of Eastern Question

The powerful influence which Germany may be able to exert on the present critical phase of the Eastern Question may perhaps give an interest to indications of popular feeling in any part of the Empire, and I therefore venture to report to Your Lordship the feeling, as far as I have been able to ascertain it of this part of Germany in regard to recent events in the East. ${ }^{1{ }^{6}}$

Though the foreign policy of this Country is not influenced by parliamentary majorities or directed by a responsible Cabinet, it can scarcely be supposed than [sic] even so powerful and implicitly trusted a Statesman as Prince Bismarck would be likely to initiate a policy opposed to the general feeling of Germany or even one unlikely to meet with a cordial support.

Great as the confidence undoubtedly reposed here in the patriotism $\&$ farsightedness of the Imperial Chancellor all parties appear to agree that silence and reserve have at the present crisis been pushed to their extreme limits, and the answer which His Highness is expected shortly

\footnotetext{
${ }^{136}$ For the Russo-Turkish War and the truce of $3^{1}$ January I878, see pp. I30-I33.
} 
to vouchsafe to the Interpellation of the German Parliament is awaited here, as probably elsewhere, with breathless anxiety. ${ }^{137}$

The divergence of views between different sections of the local press and public were very clearly marked as long as the war between Russia and Turkey was in progress. I ventured in my Despatch $\mathrm{N}^{\circ}$ 67 of October $7^{\text {th }}$ last to state what I considered to be the prevalent feeling in this part of the Country, but now that that war has practically terminated in the complete triumph of Russia and the utter collapse of Turkey, these divergent opinions seem to disappear and to be giving place to a general feeling of alarm at the preponderating position of Russia on the Eastern frontier of Europe.

Those who saw with satisfaction in the triple Alliance ${ }^{138}$ a security for the localisation of the conflict and a guarantee against any possible alliance likely to endanger the safety of the German Empire are alarmed at the prospect of a collapse of that alliance, and would gladly support any step of the German Government calculated to modify the pretensions of Russia and appease the just susceptibilities of Austria.

Intelligent persons with whom I have conversed here maintain that Germany's geographical position must always necessitate her preserving her present attitude of a Military Power armed to the teeth, watching to avert any possible alliance between the Powers on her Western and Eastern frontiers, for this reason they were prepared to approve of a benevolent neutrality on the part of Germany towards Russia, not merely in return for services rendered in 1866 and $1870^{139}$ but as the best way of discouraging an ultimate alliance between France and Russia; - without this benevolent neutrality they believe the Russian Crusade would never have attained its present success.

They admit now that the success has been more complete than they could have wished and that it has been impossible to prevent the Russian Government, or perhaps its victorious army, from overstepping the limits within which Germany could regard their advance with Complacency.

At the same time the constant uneasy dread of an ultimate 'guerre de revanche ${ }^{9_{140}}$ on the part of France disposes them to prefer a waiting

\footnotetext{
${ }^{137}$ In their joint interpellation of 8 February 1878 deputies of the liberal, progressive and conservative factions asked whether - and when - Bismarck would explain the imperial policy on the Eastern Question to the Reichstag. Bismarck responded in his speech of I9 February when, amongst other things, he declared his intention to act as an 'honest broker'.

${ }^{138}$ For the League of the Three Emperors of 1873 , see n. Io8 in Berlin section.

${ }^{139}$ Scott is referring to Russia's benevolent neutrality during the Austro-Prussian and the Franco-Prussian Wars of 1866 and I87o.

${ }^{14^{\circ}}$ 'War of revenge'.
} 
policy, convinced that any precipitate step on their side would be taken advantage of by that Power.

They are not however prepared to view with indifference a possible collapse of Austria at the risk of leaving a powerful Military State in a commanding position on their Eastern frontier; and a very intelligent German officer has expressed to me his apprehension that the last act of the Eastern drama may probably be left to be fought out by arms between Germany and Russia.

These I understand to be the feelings of those who have not disapproved of the recent attitude of Germany towards Russia. There are however others who have never concealed their entire disapproval of the policy of benevolent neutrality, regarding Russia all along with distrust as the enemy of real liberty, constitutional Government, and her policy as subversive of all International Morality.

They deplore the absence in their own country of true parliamentary Government, and complain that Germany's real interests have been sacrificed to Prussian dynastic considerations. ${ }^{141}$

Anxious for peace they are dismayed at seeing the foundations on which it rested so rudely shaken, and they would have hailed as a common savior any Power which at an earlier date might have entered the lists to maintain those foundations. Hence the bitter taunts in some of the extreme liberal papers against the inaction of England and Austria, and the severe denunciations of Russian duplicity and aggression.

The Kölnische Zeitung and Augsburg Allgemeine Zeitung represent the feelings of the more moderate but equally anti-Russian section of this press and Your Lordship's attention has probably already been called to an Article in the latter paper of yesterday's date entitled "the Policy of Germany at the decisive hour", - but I venture to enclose it herewith to Your Lordship accompanied by a Précis as it embodies very accurately a feeling very prevalent in many circles here..$^{42}$

This article after expressing doubt of the power of Austria and England to cope alone with Russian ambition energetically advocates the cooperation of Germany with those Powers for that purpose. - I note that the divergence between that Journal and its former bitter opponents is decidedly less marked than it was, and notably the Frankfurt Presse which has all along been most friendly to Russia

\footnotetext{
${ }^{141}$ Wilhelm I was Alexander II's uncle.

${ }^{142}$ Enclosures: original (Allgemeine Zeitung, No 46, ${ }_{5}$ February 1878) copy of article entitled 'Die Politik Deutschlands in der entscheidenden Stunde' ('Germany's policy in the decisive hour').
} 
and decidedly unfriendly to England, has in the last few days ceased to direct its sarcasms against the policy of the English Cabinet and to speak with derision of England's importance, using now language which at any rate denotes respect. - At the same time it sounds a note of alarm at Russia's overbearing attitude.

I have heard nothing here which would justify a Suspicion which I believe to have been sometimes entertained, that the benevolent attitude of Germany to Russia was the price stipulated for in return for future services to be rendered to Germany in view of certain undefined aggressive aims in the West, an agreement supposed to have been the object of M. de Radowitz's secret mission to St Petersburgh in $1876,{ }^{143}$ in which it was generally believed he had failed, but which I also believe some apprehend may have been partially successful the execution of the engagement being simply postponed to a more reasonable opportunity.

If such secret aims ever existed I am equally convinced that they are at variance with the feelings of many influential Germans here, who in all other respects are prepared to endorse any foreign policy initiated by the Imperial Chancellor.

At the same time I am equally convinced that any rash or precipitate step on the part of France at the present moment would entirely alter the light in which many Germans are disposed to regard the present position of affairs in the East of Europe.

\section{FO 30/247: Gharles S. Scott to Marquess of Salisbury, No 22, Darmstadt, 7 April 1878}

[Received 8 April by messenger to Cologne. For: The Queen / Lord Beaconsfield / Print / Circulate; S[alisbury]]

Local press favourable towards Lord Salisbury's circular dispatch on Russo-Turkish peace preliminaries and proposed congress

Your Lordship's Circular Despatch to Her Majesty's Embassies explaining the course pursued by Her Majesty's Government in reference to the Russo-Turkish preliminaries of peace and the proposed Congress has been translated and published in 'extenso' by most of the local papers here, and has produced an impression,

\footnotetext{
${ }^{143} \mathrm{Scott}$ is probably referring to Radowitz's mission to St Petersburg in February I875 prior to the 'War-in-Sight' crisis. Radowitz's task was to explore whether Russia would remain neutral in a further Franco-German war, if Germany were to support Russia's policy in the Balkans.
} 
generally favourable to Her Majesty's Government, in the press and Society of this part of Germany. ${ }^{144}$

The official 'Darmstadter Zeitung['] confines itself to reproducing the favourable comments of the "Kölnischer Zeitung" and of the Vienna press on the Circular, while other papers and individuals less reserved in their utterances frankly acknowledge their sympathy with the legal position assumed by Her Majesty's Government, and hail it as an indication that England's influence will be exerted in the defence of the established principles of international morality, which they consider offer the best guarantees for a durable peace, and the surest protection for the development of liberal institutions.

The Frankfort 'Neue Presse' which has hitherto adopted a tone anything but friendly to Her Majesty's Government, remarks that Your Lordship has every reason to be gratified at the reception which Your despatch has received in all parts of the Continent, and limits it's comments on it to reechoing the remarks of the Russian press that the criticism of the Treaty of S. Stephano is simply negative and suggests nothing in the place of the objectionable clauses of that Treaty.

\section{FO 30/247: Charles S. Scott to Marquess of Salisbury, No 33, Darmstadt, 24 May 1878}

[Received 3June by messenger to Cologne. For: The Queen / Lord Beaconsfield / Circulate; S[alisbury]]

Hesse vote contra coercive measures against Social Democrats; remarks on growth of Socialism in connection with depression of trade and industry in Germany

Your Lordship will have perhaps remarked that, in the late debate in the Federal Council at Berlin on the Bill for Coercive measures against the Agitation of Social-Democrats, the Grand duchy of Hesse voted with the small minority opposed to the Bill. ${ }^{45}$

The Hessian plenipotentiaries, ${ }^{14^{6}}$ I am informed, - referred by telegraph for immediate instructions as to the course they were to take, and the reply which dictated their vote was given without hesitation. This has been attributed in a great measure; by some of the local liberal papers, to the personal convictions of the present Grand Duke, who is known to be warmly attached to constitutional principles. - The vote

\footnotetext{
${ }^{144}$ In his circular dispatch of I April I878 on the Eastern Question Salisbury criticized the Treaty of San Stefano (see n. 288 in Berlin section) and demanded that all articles should be submitted to the proposed conference (Congress of Berlin; see n. 324 in Berlin section).

${ }^{145}$ For Ist draft of the anti-socialist bill, see n. 250 in Dresden section.

${ }^{146} \mathrm{Hesse}$ was represented in the Federal Council by Karl von Neidhart.
} 
at the same time faithfully expresses the convictions of the majority of the Hessian population, who, although yielding to none in their sense of horror of the late dastardly attempt on the Emperor's life, ${ }^{147}$ and prepared to strengthen the hands of the Executive in a constitutional manner against the acknowledged dangers of the Social-Democratic propaganda, believe with the leaders of the National Liberal party that these dangers can be adequately met by a firm use of the powers already at the disposal of the Executive within the limits of the existing law, and that an act of legislation ' $\mathrm{ab}$ irato ${ }^{{ }_{148} 8}$ would betray a confession of administrative weakness more calculated to strengthen than to intimidate the common enemy.

In arguing thus they cite as an example worthy of imitation the conduct of the British Government and nation during the Chartist agitation in England; ${ }^{149}$ and remind the advocates of exceptional measures that the coercive policy inaugurated in France in $185^{8}$ resulted in the Communist outbreak of 187 I. $^{15^{\circ}}$

No one acquainted with the internal history of Germany during the last ten years will affect to ignore the increasing importance and danger of the Socialist movement. The present alarming depression of German trade and industry has contributed not a little to that danger by swelling the ranks of the discontented proletariat on which the party mainly act, and by supplying the popular fallacy that the present crisis has been chiefly brought about by an international position \& foreign policy over which the masses have no effectual control.

In this respect the National Liberal party and press have been doing good service by endeavouring to expose the real causes of the present financial and commercial difficulties, shewing them to be not so much the results of political events as of peculiar vices and deficiencies latent in the existing Commercial and industrial system and practice of Germany, and of other hindrances presumably of a temporary character, which were the inevitable results of the suddenness of the organic changes by which the former barriers to the development of the united resources of the Nation were broken down.

\footnotetext{
${ }^{147}$ For the failed assassination attempt, see n. 242 in Dresden section.

${ }^{148}$ Latin: 'by one who is angry'.

${ }^{149}$ Government policy against Chartism, a largely peaceful working-class reform movement between 1838 and $c .1848$, included administrative measures and improvements to police forces, limited use of troops, and judicial punishment such as detention. No repressive legislation was introduced.

${ }^{15^{\circ}} \mathrm{Scott}$ is referring to repressive measures implemented in the aftermath of the failed assassination attempt on Napoleon III in I858, and the Paris Commune of I87I.
} 
It is generally objected that the sounder teaching of the National Liberal School of political economists has not succeeded in penetrating those lower Social layers in which the Social-Democrats work, but this is perhaps partly due to their failure to adopt the same means of disseminating their views as their more energetic antagonists.

I venture to believe that the question as to the causes of the present depression of German trade and industry is a subject of the highest importance at the present time, and that on the character - reactionary or liberal - of the remedies which may be eventually applied, will to a great extent depend not only German's commercial and industrial future but even the stability of German unity itself.

\section{FO 30/247: Charles S. Scott to Marquess of Salisbury, No 34, Darmstadt, 5 June 1878}

[Received io June by messenger to Cologne. For: The Queen / Circulate; T[enterden]]

Reactions in Darmstadt to newes of second attempt on the emperor's life

I have the honour to report that the news of the second and more serious attempt on the Emperor's life reached Darmstadt on Sunday about an hour after it occurred, - and quickly spread consternation and dismay among all respectable classes in the city. ${ }^{15}$

Tho' relieved by subsequent telegrams from immediate fears for His Imperial Majesty's life, this consternation was increased by the news of particulars tending to connect the horrible outrage with an organized conspiracy.

The predominant feeling was one of intense humiliation, many under the first impression declaring that these two crimes will go far to efface the memory of the brilliant historical achievements of Germany during the last twelve years.

The military classes especially call loudly for instant measures of force, arguing that terrorism must be met by terrorism, and that the poison of the Social democratic doctrines must be stamped out before it reaches the army, which they say they are sure of now, but "what" - they ask "are we to do when those now in the ranks return to their homes where we cannot follow their movements and where they

\footnotetext{
${ }^{15}$ On 2 June, in Berlin, Wilhelm I was shot by Karl Eduard Nobiling and seriously wounded. For the assassination attempt of I I May, see n. 242 in Dresden section.
} 
are as likely as not to fall under the influence of these dangerous agitators, it is true they will have no officers to lead them, but they may have non-commissioned officers, and are trained to combine and act in common." Some alarmists even profess to believe that a communist rising is nearer than is generally believed, and the National Liberal party is reproached with having indirectly favoured its growth.

The Liberals on their side are equally dismayed convinced that a reactionary policy will inevitably set in, which they admit will be to great extent justified, but which they fear will be carried too far, and which undertaken for the purpose of crushing licence may retard if not stifle the nascent liberty and institutions which they have so much at heart. - They reproach the Government with having themselves done much harm by coquetting at one time with the ultra radical party in order to embarrass the Liberals, and they resent the attempt of some of the Government press to judge the National Liberal party exclusively by the opinions of Herr Lasker instead of by the more moderate utterances of Herr von Beningsen $[$ sic $]$.

They deplore the absence of an energetic middle class in Germany believing that the Executive would be more effectually seconded by a strong individual expression of public opinion and by the cooperation of the respectable majority of all political parties in attacking the growing evil, than by special acts of legislation or the cannons and bayonets of their enormous military force and police.

They appeal therefore to their fellow countrymen, instead of wringing their hands over the past, mutually incriminating each other, and crying helplessly to the Government to save them, to try and see if they cannot do something themselves by individual and combined action to help the Executive in discountenancing and stifling the Social Democratic agitation.

While noting the loyal demonstrations of the respectable majority of the community which have taken the form of several public and private addresses and telegrams replete with loyalty and devotion to the Emperor, it is painful to have to record rumours of a few isolated cases in which disloyal language appears to have been used in some of the haunts of the lower classes in this neighbourhood. - These rumours and expressions may have been exaggerated in the first heat of the excitement, but they are at any rate current, and it may be well to remind Your Lordship that two of the notable chiefs of the SocialDemocratic party, Bebel and Liebknecht, though better known by their connection with other parts of Germany, are in reality natives of Hesse. 


\section{FO 30/248: William Nassau Jocelyn to Marquess of Salisbury, No 22, Darmstadt, 7 March 1879}

[Received io March by messenger to Cologne. For: The Queen / Lord Beaconsfield / Circulate; S[alisbury]]

\section{Prosecution and acquittal of Frankfurt Journal for hostile article on Prince Bismarck}

The Frankfurt Journal of which $\mathrm{M}^{\mathrm{r}}$ Sonnemann, a Member of the Diet, is the proprietor, and which represents principles of the advanced liberal section in this part of the Country, has been lately the subject of a prosecution on the part of the Imperial Government for having published a declaration hostile to the policy and insulting to the person of Prince Bismarck. ${ }^{152}$

It was further stated that the general tone of the journal in question was altogether in harmony with that of the French press upon matters relating to the German Empire, and was hence to be regarded as wanting in patriotic feeling and loyalty to the nation.

The trial was held at Frankfort a few days ago and resulted in the acquittal of the accused, - one of the Sub-editors ${ }^{153}$ being sentenced to a short term of imprisonment on a minor clause of the indictment.

It is somewhat remarkable that two out of three Judges who tried the case had quite lately been sent here from Berlin, and therefore might have been supposed to be prejudiced in favour of the Government which had appointed them.

On the announcement of the verdict the Crown Prosecutor ${ }^{154}$ immediately entered an appeal against it, which however will not be heard from $[s i c]$ some weeks.

This failure of the Ministry to establish an accusation against a journal so hostile to the policy of the Imperial Chancellor may serve as an additional proof of how unfavourably his late measures ${ }^{155}$ are likely to be received by the population of the larger Commercial centres in Germany.

\footnotetext{
${ }^{152}$ In the declaration of ${ }_{15}$ October 1878 editorial staff were reacting to Bismarck's speech made on 9 October on the occasion of the 2nd reading of the Anti-Socialist Law in the Reichstag. In this speech, Bismarck accused Sonnemann and the Frankfurter Zeitung of connections with the French government and the desire to weaken the institutions of the Empire.

${ }^{153}$ In February 1879 Josef Stern was sentenced to 7 weeks' imprisonment for criticism of Bismarck's conduct in an article dated Io October I878. On 22 April 1879 the court of appeal increased this sentence to 3 months.

${ }^{154}$ Rudolf Kunitz.

${ }^{155}$ Jocelyn is referring to Bismarck's Anti-Socialist Law of 2I October 1878 and subsequent related measures; see n. 25I in Dresden section.
} 


\section{FO 30/248: Gharles S. Scott to Marquess of Salisbury, No 40, Darmstadt, 8 May 1879}

[Received I2 May by messenger to Cologne. Print / Circulate / Mr Palgrave; S[alisbury]]

Prince Battenberg's visit to Russian emperor; hopes to return soon and visit principal courts of Europe before going to Bulgaria

I have the honour to report that Prince Alexander Battenberg left Darmstadt today for Livadia. ${ }^{15^{6}}$

I met the Prince yesterday, when he informed me of his intended visit to the Emperor of Russia, but added that he hoped shortly to return here, and that his wish was to visit the Courts of the Powers['] signatories of the Treaty of Berlin before proceeding to Bulgaria. ${ }^{157}$

I understand that he has telegraphed to Tirnova to request the Bulgarian deputation to defer their departure until he can fix the date and place for receiving them, and for signifying his formal acceptance of the Principality.

I am further informed that the Prince has expressed himself as seriously impressed with the responsibilities and difficulties of the task he has been asked to undertake, and as most anxious to merit the confidence not only of his future subjects, but also of all the Powers, with whose consent he will assume the Government of Bulgaria.

Before leaving Prince Battenberg had an audience of the Grand Duke who conferred on him the Grand Cross of the Order of Louis. - He also received a Deputation charged to offer to him the congratulations of the Municipality and Inhabitants of Darmstadt on his Election.

\section{FO 3o/248: William Nassau Jocelyn to Marquess of Salisbury, No 68, Darmstadt, 2 October 1879}

[Received 6 October by messenger. For: The Queen / Lord Beaconsfield; S[alisbury]]

Judicial change in Grand Duchy

On the $\mathrm{I}^{\text {st }}$ Instant the Unity of Procedure in Civil Matters was formally introduced by the Ministers into the Law Courts of Darmstadt, and

\footnotetext{
${ }^{156}$ Livadia Palace, the Crimean summer residence of the tsar.

${ }^{157}$ The Treaty of Berlin of I3 July I878 - whose signatories were the United Kingdom, Austria-Hungary, France, Germany, Italy, Russia, and the Ottoman Empire - created the autonomous principality of Bulgaria under the suzerainty of the Sultan of Turkey. On 29 April I879 the Bulgarian Grand National Assembly elected Alexander of Battenberg as Prince of Bulgaria.
} 
applied to the entire Grand Duchy of Hesse; thus identifying it with the rest of Germany in this respect. ${ }^{15^{8}}$

The ceremony was of an imposing character, and Baron von Starck in a very interesting and eloquent speech opened the proceedings; dwelling upon the importance of the change now brought about, and pointing out how vitally it would affect the interests of the inhabitants at large, as well as those of the members of the legal profession in particular. ${ }^{159}$

The Criminal Laws and Procedure has been, as Your Lordship is aware, uniform throughout Germany for some considerable time, ${ }^{160}$ whereas the uniform Civil Code will not be created until the Commission now sitting for the purpose in Berlin shall have terminated its labours. ${ }^{161}$

In virtue of the Ceremony of yesterday, however, the Procedure in matters before the Civil Tribunals has made an important step in advance, and all the complicated and cumbrous machinery attaching to the Roman and Canon Law, has been at once abolished.

Hitherto the Civil Procedure of the Grand Duchy was based upon these, - modified from time to time to suit the requirements of the age.

The regular Code of Law existed except in the Rhenish Hesse, where the Code Napoleon still remains the Law. ${ }^{162}$ Hence arose a perfect chaos of confusion, and decisions obscure and inequitable often resulted, as may be supposed, from this abnormal state of things, while in the Court of Bankruptcy, years of litigation were frequently spent in obtaining a decision when little was left to be awarded to the fortunate creditor.

The Givil Law in the Grand Duchy still remains, on certain minor points, of a curious and antiquated description. The feudal Barons of the Middle Ages had each given laws to their serfs, and as the territory of some seven or eight of these Lords now forms part of the Grand Duchy, the different laws and customs are still in force in the respective districts.

\footnotetext{
${ }^{158}$ The judicial reform passed by the Reichstag in 1877 came into effect in all states of the German Empire on I October 1879. It comprised imperial laws on the: constitution of the courts (27 January I877); civil procedure (30 January I877); criminal procedure (I February I877); bankruptcy (Io October I877); lawyer's practices (I Julyı878), and court fees (I8 June 1877).

${ }^{159}$ The ceremony took place at the opening of the Oberlandesgericht (higher regional court) at Darmstadt.

${ }^{160}$ The Imperial Penal Code of 15 May I87I came into force on I January I872.

${ }^{161}$ The civil code commission was instated by the Federal Council in 1874 and presented a Ist draft in I888. The Bürgerliches Gesetzbuch became effective in Igoo.

${ }^{162}$ Code Napoléon, introduced as Code civil to the areas on the left bank of the Rhine annexed to the French Empire in 1804. It remained in force until Igoo.
} 
In the case of the Laws affecting Marriage and Succession, we have in Darmstadt the Law of Katzenellbogen [sic], in Erbach, that of Erbach, while Mayence and Worms have each their own customs as regards these acts: nor is there reason to anticipate any alteration in these quaint provisions until the advent of the Great German National Code.

One of the Principal changes brought about by the recent Unification is the abolition of the secret decision of the Civil Courts.

Hitherto the judge received written evidence alone, and formed his private opinion upon it, without necessarily consulting his colleagues, delivering his verdict accordingly, whereas under the new system a college or quorum of judges varying in number from three to seven will assemble in Public, while oral evidence will be received as in our Courts, independently, however, of a Jury.

The liberty henceforward to be enjoyed by Advocates to practise in any Court throughout Germany under certain restrictions is a further result of the new arrangement - the call to the Bar being the only qualification required, and the higher Courts of Appeal alone forbidding an indiscriminate extension of the privilege. Thus a Hessian Advocate can plead in a Prussian court, except in the Highest Court of Appeal, and even in this he is at liberty to do so at the request of and as a substitute for - a Prussian colleague.

This is an important innovation, and will, perhaps, as much as any thing, tend to consolidate the unity of the various minor Nationalities under one Head.

The last point to be noticed is the reform introduced in the assessment of costs and of incidental legal expenses to claimants for justice.

A sliding scale has been devised, in virtue of which the amount of the sum under litigation will in future determine both the costs of the action and the fees to the Advocates; larger amounts in dispute carrying with them an increased bill of costs, out of all proportion to that levied on the litigants in more trifling cases, thus professing to place the poor man on fairer ground as regards the wealthy in seeking legal redress.

The fees to counsel are also revised, and the regulation by which they were prohibited from entering into a private arrangement with their clients in excess of these, has been rescinded, as inconsistent with the requirements of the present time, and as no longer open to the objection that the practice was likely to lead to useless litigation upon trivial matters.

A few changes have also been made in the conduct of magisterial and petty inquiries - and also of police investigations; but the above mentioned are those which appear to call for especial notice, as likely 
to exercise an important influence upon the future position of the Grand Duchy in the German Empire.

\section{FO 3o/248: William Nassau Jocelyn to Marquess of Salisbury, Confidential, No 79, Darmstadt, 13 November 1879}

[Received I7 November by messenger. For: The Queen / Lord Beaconsfield; T[enterden], I7 November; S[alisbury], I8 November]

\section{Prussian policy regarding German railways}

In my despatch No 77 of the Instant reporting the refusal of the Hessian Second Chamber to sanction the sale to Prussia of that portion of the Main-Weser Railway which traverses Grand Ducal Territory, ${ }^{16_{3}}$ I stated that the result of the Debate was in a great measure owing to the irritation felt by the smaller German States at the persistent endeavours of the Prussian Government to obtain not only complete administrative and financial control over, but also actual possession of all the railways North of the Main for military purposes.

They justly feel that, should Prussia succeed in acquiring it, the result will be to deprive them of the small amount of independence still left to them since the creation of the Empire, and virtually to bring under the control of the central Authority at Berlin the agricultural and commercial interests of the country through which the railways run.

An incident has recently occurred which will serve to shew the uncompromising nature of the Policy of Prussia in this direction, and the slight consideration that Government appears to entertain for equity and fairness in dealing with the interests of the smaller States, at least in railway matters.

The Rhenish Railway ${ }^{164}$ at present carries a very large proportion of the traffic between the Lower Rhine and Frankfort as far as Bingen, whence the Hessian Line conveys it to its destination.

I have learnt from a trustworthy source that during last summer a communication was made by the Minister of Public Works, M. Maybach to the Directors of the Rhenish Railway proposing to them to divert the goods traffic from Coblence to Oberlahnstein on the right

\footnotetext{
${ }^{16}{ }_{3}$ The second chamber of the Landtag dismissed the respective government bill on 3I October 1879 by 3 I to I7 votes.

${ }^{164}$ Rheinische Eisenbahn-Gesellschaft, established 1836 .
} 
bank of the Rhine and thence to Frankfort by the Nassau Railway which is in Prussian hands.

As an inducement to the Company to agree to this, the Minister offered to pay the cost of carriage of the goods between Coblence and Bingen - the terminus of the Hessian Line - as an indemnification for the loss which they would sustain by adopting the new route.

The object of this proposal was evidently to do as much damage as possible to the Hessian Line; for, considering the amount of the indemnity offered to the Rhenish Railway, no profit would have accrued to Prussia by the transaction.

I am informed that the Railway Company at once refused to entertain the proposal, or to conduct business on any but the fairest principles towards the Hessian Railway - with which they had so long been connected.

The Goods traffic which arrives at Coblence by the Moselle Line from Treves and the Rhenish Prussian Provinces en route for Frankfort, is, I am assured invariably sent by the Prussian line on the Right Bank of the Rhine instead of by the shorter Hessian railway, and this even when the goods are specially marked to be forwarded by the latter route - thus causing delay - without corresponding advantage to the receivers.

Incidents such as those given, are certainly not calculated to increase the harmony and good feeling which should exist between Prussia and the minor States - proving as they do, the growing desire of the former for self aggrandisement, without the slightest consideration for the individual interests of the latter which, in her capacity of Leader, she is called upon to promote.

\section{FO 30/249: William Nassau Jocelyn to Earl Granville, No 54, Darmstadt, 30 September 1880}

[Received II October by messenger. For: The Queen; F.S.S. [Francis S. Stephens]; G[ranville]]

\section{Death of Dalwigk}

I have the honor to inform Your Lordship that Baron von Dalwigk expired here yesterday after a long and painful illness, in the $78^{\text {th }}$ year of his age.

His Excellency entered the Hessian Service in 1828, and during his long and eventful career, filled many offices under Government, until in I850 he became Minister of State, President of the Council and Minister for Foreign Affairs. 
In concert with Monsieur von der Pfordten - recently dead - and with Monsieur de Beust, now Austrian Ambassador in Paris, Baron Dalwigk endeavoured, tho' without success, to establish the so called "Trias" in central Germany, against the struggle for the Leadership so actively carried on between Austria and Prussia, and, during the events which preceded the war of $\mathrm{I866}$, in consequence of his steadfast adherence to federal principles, he was found upon the side of Austria.

When victory had declared for the Prussian army of the Main, he retired to Munich, and subsequently joined in signing the Peace of Nicolsburg. ${ }^{16_{5}}$

The independence which the Grand Duchy obtained under the new order of things, ${ }^{166}$ enabled Baron Dalwigk to remain at the head of affairs, but eventually, in 1870 , the Convention of Versailles, ${ }^{167}$ by incorporating Grand Ducal Hesse with Imperial Germany, put an end to his political career, and he received permission from the Grand Duke to retire into private life early in I87I.

The political principles of the statesman just deceased were always reactionary and conservative in the highest degree, but, altho' on this ground his efforts cannot be said to have been crowned with success, his administrative ability has never been disputed, and the Grand Duchy owes to him much of the development of its commercial and judicial systems at a period where the advantages derived from them were still unknown to many of the neighbouring States, which then formed part of the German Confederation.

\section{FO 30/249: William Nassau Jocelyn to Earl Granville, No 56, Darmstadt, 13 October 1880}

[Received I8 October by messenger. For: The Queen / Gladstone; F.S.S. [Francis S. Stephens]; G[ranville]]

Secession from National Liberal Party in Hesse and Baden

The recent Secession from the ranks of the National Liberal Party in North Germany has been widely and seriously discussed in Hesse and Baden, and numerous meetings have been held to determine how far

\footnotetext{
${ }^{165}$ Preliminary Peace of Nikolsburg (Mikulov) of 26 July 1866; it formally concluded hostilities between Austria and Prussia.

${ }^{166}$ With the exception of the province of Upper Hesse, the Grand Duchy remained independent and was not part of the North German Confederation.

${ }^{167}$ For the so-called November Treaties, see n. I5 in this section.
} 
its members could consent to join the newly formed fraction, which has agreed no longer to be blindly led by the German chancellor. ${ }^{168}$

In Upper Hesse and in the Province of Starkenburg the result has been negative, for in the populous centres including the Capital, Mayence, Worms, and Giessen the majority have decided that the evils of an immediate secession, and the consequent weakening of the Party in the Diet far outweighed any advantages to be derived from the pursuit of such a course.

The financial measures of Prince Bismarck, ${ }^{169}$ forming as they do the basis of the movement, are naturally regarded with grave suspicion, but although the Leadership of Forckenbeck carries with it much weight, still the preponderance which would inevitably accrue to the Ultramontane and ultra Democratic Parties by the split now advocated, has alarmed the majority, and Benningsens' [sic] opinions have almost everywhere been adhered to. ${ }^{170}$

In the Grand Duchy of Baden, on the other hand, where the partisans of Secession have met with many sympathies, different elements are at work. The Ultramontane feeling is strong, and recent events, especially the divided attitude of the Chamber during the discussion of the Ecclesiastical measures brought forward last Spring have certainly not tended to weaken it. ${ }^{171}$

The Democratic Party are likewise powerful throughout a large part of the Grand Duchy, and some days ago its Leaders assembled in Carlsruhe an influential meeting of their adherents, with the object of instilling into them - activity, vigilance, and energy in view of the approaching Elections for the Diet. ${ }^{17}$

Several pungent articles have lately appeared in the public journals, especially those of the Black Forest, District, all strongly in favour of Secession - and blaming in no measured terms the change of fronts which the Chancellor has shewn towards the National Party, and the proclivities now displayed by him in favour of reaction.

The views expressed, are in general supported by an appeal to the protective measures of the new tariff, and to the evident intention of its Author to impose fiscal burdens upon the many solely for the advantage of the few.

\footnotetext{
${ }^{168}$ On 28 August I88o, a group of 28 prominent politicians resigned their membership of the National Liberals and formed the Liberale Vereinigung (Liberal Union, also called Sezession).

${ }^{169}$ Tariff Law of ${ }^{5} 5$ July I879, which levied protective duties on foreign imports, and the Law on the Taxation of Tobacco of I6 July i879.

${ }^{170}$ On I9 September I880, at a provincial party conference of the National Liberals in Hanover, Bennigsen warned against the consequences of secession for the political landscape of Germany and recommended collaborating with the Conservatives.

${ }^{171} \mathrm{Jocelyn}$ is referring to the so-called Friedensgesetz (peace law) of 5 March I880.

${ }^{172}$ The Deutsche Volkspartei held a meeting in Karlsruhe on 26 September I88o.
} 
Notwithstanding the disavowal of the adoption of secessionist principles, - at least in the present - in Hesse, and their lukewarm reception in Baden, it is evident that a fixed intention exists in both Grand Duchies among the Leaders of the National Party to spare no Endeavours to secure at the next Elections such representatives to the Diet, ${ }^{173}$ as will act altogether independent of the Chancellor, and in strict accordance with the principle which guide the party in their original and purest form.

\section{FO 30/250: William Nassau Jocelyn to Earl Granville, No roo, Darmstadt, 29 October 188 I}

[Received 3I October by messenger. For: The Queen / Gladstone; G[ranville]]

Defeat of National Liberal Party in Baden elections; remarks on electoral system

The Elections for the Baden Chamber have now terminated, and have resulted in the signal defeat of the National Liberal Party. ${ }^{174}$

In the former Chamber, it commanded a majority consisting of two thirds of the House, but it has now become evident that of the sixty three members which compose the present one, only twenty nine belong to the Party in question, the Ultramontanes having gained ten Seats, and numbering twenty five, while there are six Democrats, and three Conservatives.

This collapse of the Liberals appears to be in a great measure due to the dislike which has been gradually developing among the people to be ruled by a party numbering among its most influential members, Government officials and Ministers of State. Great havoc has been created among these in particular, and the feeling has betrayed itself in all parts of the country - the proposal of a candidate of this class being almost certain to be followed by his rejection.

Thus the Prime Minister Monsieur Turban was compelled to give way to a common peasant ${ }^{175}$ of the Village of Triberg, the Vice President ${ }^{176}$ of the late Chamber and many of the subordinate officials of State being also rejected.

The bureaucratic element was particularly strong, in the last Chamber, and being repugnant to the popular feeling, has now disappeared or has been greatly curtailed.

\footnotetext{
${ }^{173}$ The next elections for the Reichstag were due in October I88I.

${ }^{174}$ The primary elections for the second chamber of Baden Landtag took place on 3 October I88I.

${ }^{175}$ Anton Schmid.

${ }^{176}$ Carl Friderich.
} 
The Elections which have just terminated have illustrated in a remarkable manner the uselessness of the system of indirect election, on Election of Electors, which in this case has failed in securing the desired result.

The Primary Electors in many places, settled among themselves who should be returned and took care to choose only such electors as had pledged themselves to vote in favor of that candidate.

Thus the system became abortive, and I have been informed that a measure will in all probability be framed for its abolition during the session about to commence.

This double Electoral system appears quite out of date in the case of a state which has shewn such aptitude for self Government, as the Grand Duchy, and its continued existence seems all the more absurd, when it is remembered that the Elections for the Imperial Diet, which are of decidedly greater importance than those for the Local Parliaments, are conducted upon the direct system.

Both Ultramontanes and Democrats have repeatedly pronounced in favor of direct Election, and the Liberals have now learned by experience that the existing plan is not necessarily in their favor.

\title{
FO 3o/ 253: Gharles S. Scott to Earl Granville, No 42, Darmstadt, 22 April 1882
}

\author{
[Received 24 April by post. For: The Queen / Gladstone; G[ranville]]
}

Likely positions to be adopted by Baden, Hesse, and Thuringian states in Federal Council vote on tobacco monopoly

Much natural curiosity is expressed here as to the nature of the votes which will be given in the 'plenum' of the Federal Council by the Baden and Hessian Governments on the Tobacco Monopoly Question. ${ }^{177}$

Mr Jocelyn has already reported to Your Lordship that the Baden Government is by no means disposed to underrate the force of the objections entertained to the Monopoly by the Baden Chambers on financial and other grounds. ${ }^{178}$ These objections have since been

\footnotetext{
${ }^{177}$ The bill introducing the tobacco monopoly was passed - against the votes of Bavaria, Saxony, Baden, Hesse, Oldenburg, Reuß (junior line) and the Hanse towns - by the Federal Council on 24 April I882; it was subsequently rejected by the Reichstag on I8 June.

${ }^{178} \mathrm{On} 2$ I March 1882 the second chamber of the Baden Landtag passed a resolution against the introduction of the tobacco monopoly.
} 
reinforced by an exhaustive report ${ }^{179}$ submitted to the Grand Ducal Government by the Mannheim Chamber of Commerce, in which a practical and dispassionate consideration of the advantages and disadvantages likely to accrue from the introduction of an Imperial Monopoly leads up to a very decided conclusion that while the advantages will be reaped by States in the position of Wurtemberg, and in the case of Baden, by the tobacco-powers almost exclusively, - all its disadvantages will fall with special weight on Baden, in the form of financial losses to the State Exchequer, to the majority of the Communes and the great mass of the population of the $\mathrm{G}^{\mathrm{d}}$ Duchy.

It is therefore not improbable that the Baden Vote in the Federal Council will be given against the Monopoly.

The Hessian Government, - I have reason to believe, - although in principle opposed to the measure, are not prepared to give an adverse vote in the Council, with the possible result of stifling 'a limine ${ }^{980} a$ thorough examination by the Reichstag of a proposal so immediately affecting the interests of the popular constituencies.

This anticipated attitude had drawn down on the heads of Baron Starck's Ministry very severe criticisms from the local liberal journals.

No more effectual blow, - these journals believe - could be dealt by the worst enemies of the Federal Element in the Imperial Constitution, than the action of Federal Governments themselves voluntarily foregoing the exercise of their constitutional rights and duties as members of a Council, which, is a coequal factor with the Reichstag in the Legislature of the Empire, and subsiding into the position of Members of a Board of Imperial functionaries, charged with the sole duty of formulating Bills for the consideration and decision of the Popular Assembly.

I believe however that the line which the Hessian Government is supposed to be about to take is identical with that which will be adopted by other and larger States, who though equally opposed to the Monopoly Scheme, are anxious that the responsibility of its final rejection should be left to the Reichstag.

This result seems very confidently expected by the critics to whom I have referred, and the conclusion they draw from this fact is that it will hardly conduce to the stability or credit of the present Hessian Ministry, if history has to record that at an important crisis in the internal history of Germany, the vote of the Hessian Crown has been

\footnotetext{
${ }^{179}$ Denkschrift der Handelskammer für den Kreis Mannheim das Tabakmonopol betreffend, 27 March I882.

${ }^{180}$ Latin: 'at the beginning'.
} 
given in direct opposition to the ascertained sense of the country at large.

In the case of the Smaller German States, such as the Thuringian Duchies and Principalities, - I believe most of the Governments will vote for the Monopoly, altho' the majority of the population is opposed to it.

It would, I apprehend, be an act of very doubtful policy were these Minor States to set themselves in marked opposition to the known wishes of the Emperor and Imperial Chancellor; and in addition to this consideration, in these non-tobacco growing countries, where the principal sufferers by the introduction of the Monopoly would be the small retailers of tobacco - (a class comprising nearly every third shopkeeper in each town and village) - the Scheme itself holds out a very tempting bait to the State Governments with impoverished Exchequers, and rapidly diminishing returns from the Crown and State Forests.

Moreover many of the political objections valid in larger States like Baden and Hesse lose much of their force in the case of States in which the remnants of administrative independence could not be very sensibly affected by the influx of a fresh batch of Imperial officials to overlook and administer the working of the Tobacco Monopoly, in addition to the officials now managing the Railway, Postal Telegraph, and Customs Services. On the other hand the Treasuries of these States have every expectation of gaining substantial financial advantages once the Empire, adequately supported by an independent Imperial Revenue, is able to dispense with the Matricular Contributions from the Treasuries of the Federal States, ${ }^{181}$ an object which the Advocates of effective German Unity have for centuries under every form of Government vainly striven to attain.

Thus far the objections to the Tobacco Monopoly have been ostensibly based on financial considerations on which ground no doubt the question will be argued in the Federal Council, and it will be left to the Members of the Reichstag to give expression to the strong undercurrent of political objections which animate those irreconcilable fractions, who are strongly averse to placing at the disposal of an Imperial Chancellor, whom they distrust, an enormous source of revenue unfettered by the periodical control of either the Imperial or the local Parliaments.

\footnotetext{
${ }^{18}$ Matrikularbeiträge were per capita contributions made by the federal states in order to balance the deficit of the imperial budget (Article 70 of the imperial constitution of I87I).
} 


\section{FO 30/253: William Nassau Jocelyn to Earl Granville, No 87, Darmstadt, 18 September 1882}

[Received 25 September by messenger. 25 September: 'Nothing to be done upon this', Sir J. Pauncefote; 27 September: 'Shall Mr Jocelyn be instructed to convey to H.R.H the appreciation the Foreign Minister Lord Granville's appreciation of H.R.H.'s act of clemency in this case?', J.P. [Julian Pauncefote]; 27 September: 'Done'; G[ranville]]

\section{Young Englishman sentenced to ten days' imprisonment for insulting a military official}

I regret to have to report to Your Lordship an incident, which occurred in this town some weeks ago, in consequence of which a young Englishman named Reach has been sentenced by the Correctional Tribunal to ten days imprisonment without the option of a fine.

It appears that in the month of July this young gentleman, who had been studying for the English Army Examination, was bathing at the Military Bathing Place in this neighbourhood, and owing to a misunderstanding, was warned off by one of the officials on duty. He seems to have resented this, and to have applied an insulting epithet to the swimming master, with the result that he was last week summoned before the Court, and, at the hands of three judges there sitting, received the penalty I have mentioned.

It was open to Mr Reach to have appealed against the decision of the Court, but as this would have involved a further delay, which might have been followed by rejection, and as he was obliged to be in London within a few days for examination, he preferred accepting it...

I recommended him to appeal to the clemency of The Grand Duke for a remission or commutation of the sentence, which was accordingly done, and His Royal Highness, after consulting The Minister of Justice ${ }^{182}$ was pleased to remit one half of the penalty.

As no appeal was lodged, and as the Highest Judicial Authority appears to have certified to His Royal Highness that the case was one meriting punishment, nothing further can now be done, but Mr. Reach has brought a countercharge against the Military Swimming master, for using an insulting epithet to him, on the occasion of the altercation, and this will be tried by the ordinary Military Court, and the result will be communicated to me.

It does not appear to be sufficiently understood by Englishmen residing abroad, that an offensive expression, very trivial in itself, when used against a civilian, is, in Germany, magnified into a serious insult when applied to a military man in the execution of his duty, and is accordingly visited with a heavy penalty.

\footnotetext{
${ }^{182}$ Julius von Starck.
} 


\section{FO 30/253: William Nassau Jocelyn to Earl Granville, No 88, Darmstadt, 20 September 1882}

[Received 25 September by messenger. For: The Queen / Gladstone; G[ranville]]

Contrast between friendly tone of the Frankfurter Zeitung and ill-concealed feelings of jealousy and hatred in North German journals on British policy in Egypt

Although the German Press has in many instances shewn a very hostile spirit to the present policy of Her Majesty's Government in Egypt, I venture to call Your Lordship's attention to the friendly attitude which has been all along maintained by the principal Journals published in Frankfort, and more especially by the Frankfurter Zeitung the organ of M. Sonnemann one of the most advanced liberals of that town.

This Newspaper, which expresses the opinion of the Majority of the great commercial Centre of Germany contained a leading Article a few days ago, the tone of which has induced me to trouble Your Lordship with it.

The Article commences by sketching the advantageous position obtained in Egypt by the British troops after the victory of Tel-el$\mathrm{Kebir}^{183}$ and inveighs in very forcible language indeed against that held by some of the influential journals of North Germany, which had predicted disaster to our arms, and have done so with ill-concealed feelings of jealousy and hatred -- an ungrateful return for the friendly feelings to Germany evinced by the English Press during the Franco German War...

In conclusion opinions are expressed upon our policy and upon the probable consequences of it in the East.

I have extracted this part of the Article, and accompanied it with a translation which I venture to inclose herewith in case it should prove of interest to Your Lordship. ${ }^{184}$

\footnotetext{
${ }^{183}$ For the Battle of Tel-el-Kebir of ${ }_{13}$ September I882, see n. 431 in Berlin section.

${ }^{18}{ }_{4}$ Enclosure: clipping and translated extract from the Frankfurter Zeitung (No 259 of 6 September 1859).
} 


\section{FO 30/256: Charles S. Scott to Earl Granville, No 32, Darmstadt, 13 April 1883}

[Received I6 April by Messenger Ewen. For: The Queen / Prince of Wales; G[ranville]]

Irritation caused by The Times article alluding to dishonourable conduct of Hessian army in I870

The Times Newspaper of the $7^{\text {th }}$ instant contains a telegram from its Paris Correspondent ${ }^{185}$ drawing attention to certain passages in the private correspondence of the late Herr Stieber who was attached, on Police Service, to the General Staff of the German Army in I870-7I.

These passages cast very serious reflections on the conduct of the Hessian troops during the Franco-German War, and assert that six Hessians were arrested by order of Prince Frederick Charles in the Act of pillaging the deserted town of Faulquemont, and would have been shot but for Herr Stieber's intervention. The writer adds, "these Hessians are perfect bandits but good soldiers."

Herr Stieber's authority was not held in sufficient estimation to entitle his opinion to much weight in Germany, but the fact of his so-called Memoirs being published by a Prussian Paper - the Berlin Tageblatt ${ }^{186}$ - with special attention drawn to the obnoxious charges against the Hessian and Bavarian troops, aroused a very great and natural amount of indignation in all quarters civil as well as military here, and a prompt refutation and explanation of the particular incident referred to was published in the official Darmstadt paper, by order of the Commander of the Hessian Division, Prince Henry of Hesse.

A sharp reprimand was subsequently administered to the Berlin Tageblatt by the Semi official Norddeutsche Allgemeine Zeitung for giving currency to such unfounded aspersions on the honour of a highly distinguished and brave portion of the German Army. The incident was then considered here as satisfactorily disposed of and not deserving of further notice.

\footnotetext{
${ }^{185}$ Henri Opper de Blowitz.

${ }^{186}$ The Denkwuirdigkeiten des Geh. Regierungsrathes Dr. Stieber, ed. Leopold Auerbach, were published in several instalments in the Berliner Tageblatt from September I882; the passage in question on 6 March 1883 .
} 
I have the honour to enclose herewith copy and translation of the Hessian refutation, which seems entirely to exonerate the Hessian Army from the charges of pillaging. ${ }^{187}$

The reappearance of the Same charges in the columns of a paper enjoying the reputation and influence of the London "Times", without any mention of the Hessian official Refutation, has caused considerable surprise and, I regret to say, much irritation in military circles at Darmstadt.

A hope has been expressed in high quarters that the Times may be induced to give the same publicity to the refutation as it has done to the charges made against the Hessian troops.

\section{FO 30/256: William Nassau Jocelyn to Earl Granville, No 8o, Darmstadt, 23 August 1883}

[Received ı September by messenger. For: The Queen; G[ranville]]

Attitude of Conservative Party in Baden in context of impending elections

The approaching elections for the Grand Duchy of Baden have aroused the spirit of the Conservative party, who are exerting themselves to strengthen their representation in the chamber, by endeavouring to throw discredit upon their National Liberal opponents. ${ }^{188}$

With this object in view, the organs of the Party have not scrupled to assert that not only the Government of the Country have assumed a lukewarm and undecided attitude towards continuing a Liberal Policy but that the views of The Grand Duke himself had undergone a change in this respect and that His Royal Highness had ceased to maintain those principles of which he has ever since r86o been the loyal supporter.

In opposition to these declarations and greatly to the relief of the National Liberal feeling throughout the Grand Duchy, The Minister of State Monsieur Turban has been instructed by His Sovereign to give a positive denial to these assertions, and especially as regards Himself to state that He had not in the slightest degree wavered from His political views and intentions, but that $\mathrm{He}$, on the contrary, holds

\footnotetext{
${ }^{187}$ Enclosure: original (undated clipping from Darmstädter Zeitung) and translation of the declaration of the Commander of the Grand Ducal Hessian (25th) Division, dated I9 March I883.

${ }^{188}$ The elections were to be held on ${ }_{4} 4$ September 1883.
} 
as firmly as ever to the development of the national institutions of the country.

This communication, ${ }^{189}$ so important in the present condition of affairs, was sent to the principal officials throughout the Grand Duchy, and its publication, will doubtless make a deep impression upon those citizens who, having hitherto trusted to the wise counsels of their Prince, and followed His political lead, have nevertheless felt perplexed and disturbed by the confident assertions and covert insinuations lately put forward by the Conservative organs.

${ }^{189}$ Edict (Wahlerlaß) of 25 August I883. 